\title{
Eddy-mediated biological productivity in the Bay of Bengal during fall and spring intermonsoons
}

S. Prasanna Kumar, M. Nuncio, N. Ramaiah, S. Sardesai, Jayu

Narvekar, Veronica Fernandes, Jane T. Paul

National Institute of Oceanography, Dona Paula, Goa-403 004, India.

\begin{abstract}
The signature of cold-core eddies and their role in altering the biological productivity of the Bay of Bengal was examined using two recent sets of hydrographic data collected along the central and western Bay of Bengal during fall (14 September - 12 October, 2002) and spring (12 April - 7 May, 2003) intermonsoons under the Bay of Bengal Process Studies (BOBPS) programme. Based on the thermohaline structure and the satellite-derived sea-level anomaly maps 9 cyclonic eddies were identified. Out of this, 4 cyclonic eddies -2 each along the central Bay and along the western boundary - occurred during fall intermonsoon 2002, while 5 occurred -3 along the central Bay and 2 along the western boundary - during spring intermonsoon. The eddy depressed the temperature, which varied from $3^{\circ} \mathrm{C}$ to $7^{\circ} \mathrm{C}$ at $120 \mathrm{~m}$ depth. Maximum depression of temperature was associated with spring-time eddies in the northern Bay, where subsurface stability was low. The reduced water column stability in spring leads to greater eddypumping, thereby cooling the water to a greater extent. However, the cyclonic eddies were unable to break the stratification of the top $20 \mathrm{~m}$ layer, thereby curtailing their effects below this depth during both seasons. Eddypumping not only cooled the water column but also enhanced the nutrient concentrations. This in turn increased the biological productivity of the Bay to $1 \frac{1}{2}-2$ times. In addition, the subsurface chlorophyll maximum (SCM), which is generally located between 40 and $70 \mathrm{~m}$ in fall and 60 and $90 \mathrm{~m}$ in spring intermonsoons, shallowed under the influence of the eddies and also enhanced the chlorophyll concentration in the SCM to more than double. Thus, eddy-pumping of nutrients controls the biological productivity of the Bay of Bengal during both the seasons. In the fall intermonsoon, however, the riverine input of nutrients and sediments in the northern Bay also plays a role in altering the biological productivity. This has an overall implication to the basin-wide new production and export flux and, at least partly, resolves the reason for the comparable annual fluxes of organic carbon
\end{abstract}


between the high-productivity Arabian Sea and low-productivity Bay of Bengal.

\section{Introduction}

The Bay of Bengal, bounded in the north at around twenty-two degrees, is a tropical basin situated in the eastern part of the northern Indian Ocean. The dominant atmospheric forcing is the semi-annually reversing monsoon winds, southwesterly during June-September (summer/southwest monsoon) and northeasterly during November-February (winter/northeast monsoon), which causes a semi-annual reversal of the surface circulation as well. On an annual scale this basin receives excess precipitation over evaporation to the tune of $\sim 2 \mathrm{~m} \mathrm{yr}^{-1}$ (Prasad, 1997), while the runoff from the peninsular rivers amounts to about $1.625 \times 10^{12} \mathrm{~m}^{3} \mathrm{yr}^{-1}$ (Subramanian, 1993). The suspended sediment discharge associated with the river runoff into the Bay is estimated to be about $1.382 \times 10^{9}$ tonnes $\mathrm{yr}^{-1}$ (Subramanian, 1993). The excess precipitation over evaporation and runoff freshen the upper layer waters of the basin. As a result, the annual mean surface salinity ranges from 30 (practical salinity scale) in the north to 34 towards the southern part (Fig.1). Apart from freshening of the surface layers, the river discharge is expected to add nutrients to the upper layers and increase the biological productivity of the Bay. However, recent measurements using clean techniques (Madhupratap et al., 2003) corroborate the traditional concept that the Bay of Bengal is a region of lesser biological productivity. The reason for this is variously attributed to cloud cover, large sediment load, narrow shelf, stratification, etc (see Qasim, 1977; Sengupta et al., 1977; Radhakrishna, 1978; Gomes et al., 2000). In a recent study Prasanna Kumar et al. (2002) 
showed that the surface and the integrated chlorophyll $a$ in the Bay of Bengal during summer monsoon was 4-5 times lesser than that in the Arabian Sea while the integrated primary productivity was about 8 times less. Based on the physical forcing, Prasanna Kumar et al. (2002) argued that this low biological production stems primarily from the lack of availability of nutrients in the upper layers arising from strong stratification and weaker winds, which curtail vertical mixing.

Contrary to the above pattern of chlorophyll and primary productivity in the Arabian Sea and the Bay of Bengal, sediment trap data shows that the average annual fluxes of organic carbon are comparable in both basins (Ramaswamy and Nair, 1994). This is intriguing considering the fact that there is no evidence of strong upwelling in the Bay of Bengal except for very localized upwelling close to the southwestern boundary during summer (Murty and Varadachari, 1968; Shetye et al., 1991) and that the comparatively weaker winds are unable to break the strong upper ocean stratification through wind-driven mixing. Thus, in the Bay of Bengal the traditional mechanisms of nutrient supply to the oligotrophic upper ocean waters such as wind-driven mixing, upwelling, aeolian dust input, etc. cannot account for the annual particle flux collected in sediment traps. Based on 2001 summer monsoon data, Prasanna Kumar et al. (2004) identified cold core eddies in the Bay of Bengal and proposed eddy pumping as a possible mechanism of vertical transfer of nutrients across the halocline to the oligotrophic euphotic zone during summer monsoon, when the upper ocean is highly stratified. This cold-core eddy was found to enhance the biological productivity by more than double. Though the existence of eddies in the Bay of Bengal has been documented by several authors (Ramasastry and Balaramamurty, 1957; Rao and Sastry, 1981; Legeckis, 1987; Babu et al., 
1991; Murty et al., 1993; Shetye et al., 1993; Sanilkumar et al., 1997; Babu et al., 2003; Madhusoodhanan and James, 2003; Prasanna Kumar et al., 2004) their role in the context of biological production is yet to be explored fully. An attempt towards this was made by Prasanna Kumar et al. (2004) using data collected during summer monsoon. In the present paper we examine the hydrographic data collected during fall and spring intermonsoons in the Bay of Bengal to identify the signature of eddies and explore their role in altering the biological productivity. The spring (MarchApril) and the fall (September-October) intermonsoon seasons represent the primary and secondary heating season in the Bay of Bengal during which the winds are weak and variable (Narvekar and Prasanna Kumar, 2006). The fresh water discharge from peninsular rivers is the least during spring intermonsoon, while it is at its peak during end of summer and beginning of fall intermonsoon (August-September). Unlike this, the summer (JuneAugust) monsoon is characterized by strong $(\sim 10 \mathrm{~m} / \mathrm{s})$ and organized winds from southwesterly direction and high precipitation.

\section{Data and method}

As a part of the Bay of Bengal Process Studies (BOBPS) to understand the seasonal cycle of the upper ocean variability and associated changes in the biogeochemistry, in situ measurements were carried out onboard ORV Sagar Kanya along two transects - in the central Bay and along the western boundary (Fig.1) - during fall (14 September - 12 October, 2002) and spring (12 April - 7 May, 2003) intermonsoons. The measurements in fall intermonsoon were aimed at capturing the effect of freshwater in put, while those in spring intermonsoon were to understand the effect of solar heating. In all 24 CTD (Conductivity-Temperature-Depth) stations were occupied at 
1-degree intervals, 14 in the central Bay of Bengal along $88^{\circ} \mathrm{E}$ and 10 along the western boundary. A Sea-Bird CTD having a rosette sampler fitted with 10/30-L Go-Flo bottles was used to obtain profiles of temperature and salinity in the upper $1000 \mathrm{~m}$. CTD salinity was calibrated against water samples collected simultaneously and analyzed with a Guildline 8400 Autosal. Water samples collected from various depths were analyzed for nitrate and silicate using a spectrophotometer. The detection limits for nitrate and silicate were 0.1 and $0.5 \mu \mathrm{M}$, while standard deviations were 0.02 and $0.05 \mu \mathrm{M}$ respectively.

In addition to the high-resolution physical and chemical measurements, nine biological stations (5 in the central Bay of Bengal and 4 along he western boundary) (Fig.1) were also occupied for over $24 \mathrm{~h}$ for measuring primary production according to an in situ incubation protocol (UNESCO, 1994). Details of these measurements are reported in Madhupratap et al. (2003). Briefly, water samples collected at pre-dawn from eight discrete depths (near surface, 10, 20, 40, 60, 80, 100 and $120 \mathrm{~m}$ ) by the CTD rosette sampler were used for measuring primary production (PP). Water samples from each depth were collected into four $300 \mathrm{ml}$ polycarbonate (Nalgene, Germany) bottles (three light, one dark). One ampoule of $\mathrm{NaH}^{14} \mathrm{CO}_{3}$ (specific activity of $185 \mathrm{kBq}$; Board of Radiation and Isotope Technology, Mumbai) was added to each bottle. Following this, all bottles were tied on to a mooring system before dawn and, incubated in situ at respective depths for 12h. The mooring was in situ from just-before-sunrise to half hour past sunset. Uptake of ${ }^{14} \mathrm{C}$ was measured by filtering $100 \mathrm{ml}$ of sample from each bottle through $\mathrm{GF} / \mathrm{F}$ filters ( $25 \mathrm{~mm}$ dia, $0.7 \mu \mathrm{m}$ pore size, Whatman, USA); filters transferred into scintillation vials and exposed to $\mathrm{HCl}(0.5 \mathrm{~N})$ fumes 
overnight in a closed container. Five ml liquid scintillation cocktail (Sisco Research Laboratory, Mumbai) was added to each vial and, assayed for radioactivity in a scintillation counter (Wallac 1409 DSA, Perkin Elmer, USA). PP rate was calculated and expressed as $\mathrm{mg} \mathrm{C} \mathrm{m}^{-3} \mathrm{~d}^{-1}, 12 \mathrm{~h}$ being considered as day (UNESCO, 1994). Chlorophyll $a$ (chl $a$ ) concentrations from samples collected at all the depths mentioned above were measured using a fluorometer (Turner Designs, USA). Sub-samples from these depths were filtered through $47 \mathrm{~mm} \mathrm{GF} / \mathrm{F}$ filters and, the chl $a$ was extracted in 10 $\mathrm{ml} 90 \%$ acetone in the dark for $24 \mathrm{~h}$ in a refrigerator and its concentration determined. Surface meteorological observations were also made along both tracks, and all the above measurements followed the JGOFS protocols (UNESCO, 1994). From the temperature and salinity data, geostrophic currents were computed with respect to $1000 \mathrm{~m}$ depth following the HellandHansen method (Pond and Pickard, 1978).

In addition to the in situ hydrographic data, we also used remote sensing data on sea-level height and chlorophyll pigment concentrations. The 7-day snapshots of the merged sea-level anomalies of Topex-Posiedon/ERS 1/2 satellites obtained from the AVISO (http://las.aviso.oceanobs.com) live access server having a spatial resolution of $1 / 3$ of a degree, were examined during September-October 2002 and April-May 2003 to obtain the spatial structure of eddies inferred from the hydrographic data. From the sea-level anomalies velocities were computed assuming the geostrophic relation $2 \Omega \sin (\phi) . \mathrm{V}=\mathrm{g} \tan (\mathrm{i})$, where $\Omega$ is the earth's angular velocity, $\phi$ is the latitude, $\mathrm{V}$ is the velocity and $\tan (\mathrm{i})$ is the slope of the sea surface (Pond and Pickard, 1978). 
The monthly mean chlorophyll pigment concentration data was derived from (http://reason.gsfc.nasa.gov/OPS/Giovanni/ocean.seawifs.shtm) SeaWiFS global 9-km monthly imagery.

\section{Results}

\subsection{Fall intermonsoon 2002}

\subsubsection{Thermohaline structure}

Thermal structure along the central Bay transect showed a shallow upper isothermal layer of about $20 \mathrm{~m}$ thickness in the south, which deepened to about $70 \mathrm{~m}$ at $11^{\circ} \mathrm{N}$ and then shoaled towards the north (Fig.2a). The temperature of this layer was about $28^{\circ} \mathrm{C}$ except in the northernmost regions $\left(18-20^{\circ} \mathrm{N}\right)$, where it was $1^{\circ} \mathrm{C}$ higher. The thermocline was characterized by oscillations and exhibited a gradual shoaling towards north. Three regions could be identified with well defined upward sloping followed by downward sloping centered at $8^{\circ} \mathrm{N}, 14^{\circ} \mathrm{N}$ and $18^{\circ} \mathrm{N}$. For example, the $22^{\circ} \mathrm{C}$ isotherm showed a $30-\mathrm{m}$ shoaling in all the three regions from about $100 \mathrm{~m}$ to $70 \mathrm{~m}$ at $8^{\circ} \mathrm{N}, 110 \mathrm{~m}$ to $80 \mathrm{~m}$ at $14^{\circ} \mathrm{N}$, and $90 \mathrm{~m}$ to $60 \mathrm{~m}$ at $18^{\circ} \mathrm{N}$. In general, the

up/down sloping depressed the ambient temperature by about $3^{\circ} \mathrm{C}$ in all three regions. It may be noted that the influence of the up/down sloping was discernible even in the upper $50 \mathrm{~m}$ in the case of oscillations centered at $8^{\circ} \mathrm{N}$ and $18^{\circ} \mathrm{N}$, while that at $14^{\circ} \mathrm{N}$ was confined mostly below $80 \mathrm{~m}$. Below 300 $\mathrm{m}$, however, the oscillations in the isotherms were very small.

The vertical salinity structure showed the presence of very low salinity waters in the surface, as low as 29, in the northern region (Fig.2b). The surface salinity increased rapidly towards the south attaining the maximum 
value of 34. The salinity front arising from the freshening of waters from the north was confined mainly to the upper $50 \mathrm{~m}$ and north of $12^{\circ} \mathrm{N}$. As a result, salinity distribution also showed a strong vertical gradient with an increase in salinity of about 5.5 in the upper $50 \mathrm{~m}$. The vertical gradient weakened towards the south with an increase in salinity of 1 in the upper $80 \mathrm{~m}$. Below $50 \mathrm{~m}$ and down to $1000 \mathrm{~m}$ the salinity remained almost same. The up/down sloping of isohalines, though weakly perceptible in the region of $17-18^{\circ} \mathrm{N}$, was absent near $8^{\circ} \mathrm{N}$ and $14^{\circ} \mathrm{N}$. This was due to the weak salinity gradient towards the south and below $80 \mathrm{~m}$.

The density (sigma-t) distribution essentially reflected 3 prominent regions of isopycnal doming (Fig.2c) coinciding with those seen in the thermal structure, apart from the strong density stratification in the north associated with the salinity gradient.

Along the western boundary, the thermal structure exhibited a warmer (in excess of $\left.30^{\circ} \mathrm{C}\right)$ and shallower $(\sim 10 \mathrm{~m})$ isothermal layer except in the south and north where it was colder $\left(\sim 29^{\circ} \mathrm{C}\right)$ and thicker (in excess of $20 \mathrm{~m}$ ) (Fig.3a). The most distinct features were two prominent regions of upward isotherm sloping followed by a downward sloping located at $12^{\circ} \mathrm{N}$ and $18^{\circ} \mathrm{N}$, respectively (Fig.3a). The doming of isotherms was more pronounced at $18^{\circ} \mathrm{N}$ with the $22^{\circ} \mathrm{C}$ isotherm showing a vertical displacement of $50 \mathrm{~m}$ from $110 \mathrm{~m}$ to $60 \mathrm{~m}$, while that at $12^{\circ} \mathrm{N}$ shoaled by about $30 \mathrm{~m}$. This upward/downward sloping of isotherms lowered the temperature by about $3^{\circ} \mathrm{C}$ at $12^{\circ} \mathrm{N}$ and $5^{\circ} \mathrm{C}$ at $18^{\circ} \mathrm{N}$. Unlike the central Bay of Bengal thermal structure, the oscillation of isotherms at $12^{\circ} \mathrm{N}$ penetrated deeper than the thermocline and was noticed even down to $900 \mathrm{~m}$.

The surface salinity showed fresher waters in the north compared to the central Bay with salinity as low as 25 (Fig.3b). The salinity structure 
remained more or less similar to that of the central Bay, but with much stronger vertical gradients. However, the upward/downward sloping of isohalines was much sharper and more pronounced at $18^{\circ} \mathrm{N}$ in comparison with the central Bay. At $12^{\circ} \mathrm{N}$ the isohaline below $500 \mathrm{~m}$ also showed upward/downward sloping.

Once again the density (sigma-t) structure showed features similar to that of the thermal structure along with very strong stratification of the upper layers in the north (Fig.3c).

\subsubsection{Geostrophic currents}

The geostrophic velocities computed from temperature and salinity profiles showed alternate bands of positive (eastward) and negative (westward) flows along both transects (Fig.4). Along the central Bay transect the flow was eastward between 7 and $8^{\circ} \mathrm{N}$ with a speed of $20 \mathrm{~cm} / \mathrm{s}$ at $8^{\circ} \mathrm{N}$, which decreased towards $9^{\circ} \mathrm{N}$ and turned into a westward flow with maximum speed of $25 \mathrm{~cm} / \mathrm{s}$ at $11^{\circ} \mathrm{N}$ (Fig.4a). Once again, the flow was eastward between $12^{\circ}$ and $14^{\circ} \mathrm{N}$ with maximum speed of $25 \mathrm{~cm} / \mathrm{s}$. Currents, in general, were weak $(\sim 5 \mathrm{~cm} / \mathrm{s})$ and westward north of $15^{\circ} \mathrm{N}$, except for a region between $16^{\circ}$ and $18^{\circ} \mathrm{N}$ where a weak $(10 \mathrm{~cm} / \mathrm{s})$ and shallow $(\sim 70 \mathrm{~m})$ eastward flow was encountered. It may be noted that the flows with speed greater than $10 \mathrm{~cm} / \mathrm{s}$ were confined to the upper $150 \mathrm{~m}$.

Along the western boundary (Fig.4b), the flow was eastward at $11^{\circ} \mathrm{N}$ with a speed of $20 \mathrm{~cm} / \mathrm{s}$, which gradually decreased to a minimum at $12^{\circ} \mathrm{N}$ and turned to a westward flow of magnitude $20 \mathrm{~cm} / \mathrm{s}$ centered $13^{\circ} \mathrm{N}$. The current changed its direction towards the east at $16^{\circ} \mathrm{N}$ with speed increasing to $\sim 20$ $\mathrm{cm} / \mathrm{s}$ between 16 and $17^{\circ} \mathrm{N}$ followed by another change in direction towards the west. The maximum speed of this westward current was about $25 \mathrm{~cm} / \mathrm{s}$ 
between 18 and $19^{\circ} \mathrm{N}$. Here again, the flows with speed greater than 10 $\mathrm{cm} / \mathrm{s}$ were confined to $150 \mathrm{~m}$, except between $11^{\circ}$ and $13^{\circ} \mathrm{N}$.

In general, the computed geostrophic flow reversals were associated with the upward/downward sloping of isotherms/isopycnals observed in the thermohaline structure. The eastward flow corresponds to the region of upward sloping while the westward flow coincides with downward sloping of isotherms/isopycnals. Thus, the alternating zonal flows associated with the doming of isopleths in the thermohaline structure appear to be a part of the cyclonic circulation feature and we infer them to be the signature of a cold-core eddy. In order to establish this, we analyzed the 7-day sea-level anomaly maps during 18 September to 15 October 2002 (Fig.5). Note that the CTD measurements along the central Bay transect were during 17 to 27 September 2002, while those along the western boundary were during 30 September to 11 October 2002. Hence the left panel in Fig.5 represents sealevel anomaly during the central Bay transect sampling period, while that in the right panel represents the sea-level anomaly during the sampling period along western boundary.

In the sea-level anomaly maps, we noticed two cyclonic eddies in the north centered at $17^{\circ} \mathrm{N}, 88^{\circ} \mathrm{E}$ and $17.5^{\circ} \mathrm{N}, 85^{\circ} \mathrm{E}$, embedded in a large cyclonic circulation between $84^{\circ}$ and $89^{\circ} \mathrm{E}$ longitude and $14^{\circ}$ and $19^{\circ} \mathrm{N}$ latitude (Fig.5). This was consistent with the geostrophic flow computed from the hydrographic data, which showed a large cyclonic circulation with eastward flow between $12^{\circ}$ and $14^{\circ} \mathrm{N}$ and a westward flow north of it extending up to $19^{\circ} \mathrm{N}$. Note that in situ measurements sampled both eddies, one along the central Bay transect and the other along the western boundary track, away from its center. Similarly, two more cyclonic eddies - one centered at $12^{\circ} \mathrm{N}$, $82^{\circ} \mathrm{E}$ near the western boundary and the other at $8.5^{\circ} \mathrm{N}, 87^{\circ} \mathrm{E}$ in the central 
Bay transect - were visible in the sea-level anomaly maps. These eddies depressed the sea level by about $20-25 \mathrm{~cm}$. The sea-level anomaly map showed that the CTD station at $14^{\circ} \mathrm{N}$ along the central Bay transect falls at the edge of the large cyclonic circulation within which the two northern cyclonic eddies - central Bay and along the western boundary - were embedded (Fig.5). Thus, it is evident from the sea-level anomaly maps that there were only 4 distinct cyclonic eddies, two each along the open ocean and along western boundary, which were sampled during fall intermonsoon 2002.

\subsubsection{Nutrients}

Consistent with thermal structure, the vertical distributions of nitrate along the central Bay transect also showed oscillations and a general northward shoaling of isopleths in the upper ocean (Fig.6a). The doming of isopleths centered at $8^{\circ} \mathrm{N}, 14^{\circ} \mathrm{N}$, and $18^{\circ} \mathrm{N}$, in general, coincided with the locations of eddies identified from the thermohaline structure as well as from the sealevel anomaly maps, except that at $14^{\circ} \mathrm{N}$, which was located at the edge of a large cyclonic circulation. The upper $20 \mathrm{~m}$, however, showed concentrations below detection level; the $1 \mu \mathrm{M}$ nitrate isopleth, which was generally located close to $50 \mathrm{~m}$, shoaled to about $25 \mathrm{~m}$ in the south (south of $15^{\circ} \mathrm{N}$ ) under the influence of the doming while in the north it shoaled to shallower than $10 \mathrm{~m}$. Silicate showed a distribution similar to that of nitrate below $30 \mathrm{~m}$ (Fig.6b). However, unlike the nitrate the silicate levels were high in the upper $30 \mathrm{~m}$. The surface silicate concentrations increased from $0.5 \mu \mathrm{M}$ in the south to 2 $\mu \mathrm{M}$ in the north. 
Along the western margin, the prominent features in the nitrate distribution were two regions of doming isopleths, centered at $12^{\circ} \mathrm{N}$ and $17.5^{\circ} \mathrm{N}$ (Fig.6c), which coincided with the locations of eddies inferred from the thermohaline structure and the sea-level anomaly maps. The top $20 \mathrm{~m}$ was devoid of nitrate except in the north and south where the doming introduced nitrate to shallower than $10 \mathrm{~m}$. In fact, the $1-\mu \mathrm{M}$ nitrate isopleth was deepest at $16^{\circ} \mathrm{N}$ and shoaled under the influence of eddies. Silicate also showed a distribution similar to that of nitrate below $20 \mathrm{~m}$ (Fig.6d). In the upper $20 \mathrm{~m}$, unlike the nitrate pattern, high silicate levels were encountered towards the north with surface concentrations increasing from $5 \mu \mathrm{M}$ at $17^{\circ} \mathrm{N}$ to $15 \mu \mathrm{M}$ at $19^{\circ} \mathrm{N}$. This high surface concentration, which decreased rapidly in the upper $30 \mathrm{~m}$, suggests a source in the north.

\subsubsection{Chlorophyll $a$ and primary productivity}

Chlorophyll $a$ in the top $120 \mathrm{~m}$ along the central Bay transect varied from $0.12 \mathrm{mg} / \mathrm{m}^{3}$ to $0.37 \mathrm{mg} / \mathrm{m}^{3}$, with higher values towards south (Fig.7a). The most prominent feature was the occurrence of enhanced chlorophyll $a$ concentrations, which coincided with the location of eddies inferred from the thermohaline structure and sea-level anomaly maps. In fact, the top $40 \mathrm{~m}$ of the water column in the eddy region contained the highest chlorophyll concentrations. The subsurface chlorophyll maximum (SCM), which was generally located at $60 \mathrm{~m}$, shoaled under the influence of the eddy. As a result, very low chlorophyll $a$ concentrations $\left(<0.05 \mathrm{mg} / \mathrm{m}^{3}\right)$, which occurred below $80 \mathrm{~m}$ in the south (south of $15^{\circ} \mathrm{N}$ ), also shoaled $(\sim 60 \mathrm{~m})$ towards the north. Surface primary production (PP) varied from 5.34 to $17.66 \mathrm{mg} \mathrm{C} \mathrm{m}^{-3}$ $\mathrm{d}^{-1}$, while column integrated PP (up to 120 ) ranged from 513 to $182 \mathrm{mg} \mathrm{C} \mathrm{m}^{-}$ 
${ }^{2} \mathrm{~d}^{-1}$ (Table 1). Here again, the higher values of PP, both surface and column integrated, occurred in the eddy region, except at $18^{\circ} \mathrm{N}$.

Along the western boundary surface chlorophyll $a$ concentrations varied marginally from 0.13 to $0.18 \mathrm{mg} / \mathrm{m}^{3}$ except at $19^{\circ} \mathrm{N}$ and at $16^{\circ} \mathrm{N}$ where the highest $\left(0.77 \mathrm{mg} / \mathrm{m}^{3}\right)$ and lowest $\left(0.08 \mathrm{mg} / \mathrm{m}^{3}\right)$ values occurred respectively (Fig.7b). Though enhanced chlorophyll concentrations were seen in the eddy region, unlike the open ocean, the concentrations were more prominent and uniformly distributed in the north (in the vicinity of $18^{\circ} \mathrm{N}$ ) than the south. This is also reflected in the surface and column-integrated PP. Surface PP varied from 3.16 to $45.15 \mathrm{mg} \mathrm{C} \mathrm{m}^{-3} \mathrm{~d}^{-1}$, while the columnintegrated values ranged from 196 to $350 \mathrm{mg} \mathrm{C} \mathrm{m}^{-2} \mathrm{~d}^{-1}$. Though the eddy caused the nitracline to shoal both in the north and in the south along the central Bay, the column-integrated PP was highest in the south, more than $2 \frac{1}{2}$ times that in the north. In fact, it was also $1 \frac{1 / 2}{2}$ times higher than the highest PP in the north along the western boundary.

\subsection{Spring intermonsoon 2003}

\subsubsection{Thermohaline structure}

Thermal structure along the central Bay transect during spring intermonsoon showed a thin isothermal layer of about $10 \mathrm{~m}$ in the south, south of $15^{\circ} \mathrm{N}$, within which the temperature was in excess of $30^{\circ} \mathrm{C}$ (Fig.8a). Towards the north, the isothermal layer was thicker $(\sim 30 \mathrm{~m})$ and $1{ }^{\circ} \mathrm{C}$ colder. In general, the isotherms in the upper $50 \mathrm{~m}$ showed a shoaling trend from $7^{\circ} \mathrm{N}$ to $15^{\circ} \mathrm{N}$, while further north it deepend towards $17^{\circ} \mathrm{N}$ and once again shoaled at $19^{\circ} \mathrm{N}$. However, below $50 \mathrm{~m}$ there was a reversal in the slope of the isotherms, which showed a deepening trend from $7^{\circ} \mathrm{N}$ towards $18^{\circ} \mathrm{N}$. As 
during the fall intermonsoon, we noticed oscillations in the thermocline and three distinct regions of isotherm upward sloping followed by downward sloping centered at $11^{\circ} \mathrm{N}, 16^{\circ} \mathrm{N}$ and $19^{\circ} \mathrm{N}$. At $11^{\circ} \mathrm{N}$, the upward/downward sloping of isotherms was the least, while at $19^{\circ} \mathrm{N}$ it was at a maximum. For example, the $22^{\circ} \mathrm{C}$ isotherm shoaled by about $20 \mathrm{~m}$ at $11^{\circ} \mathrm{N}$ and $16^{\circ} \mathrm{N}$, which depressed the temperature at $120 \mathrm{~m}$ by $2-3^{\circ} \mathrm{C}$. At $19^{\circ} \mathrm{N}$ the shoaling exhibited by the $22^{\circ} \mathrm{C}$ isotherm was as large as $70 \mathrm{~m}$, which resulted in a drop in the temperature by about $7^{\circ} \mathrm{C}$ at $120 \mathrm{~m}$. The upward/downward sloping of isotherms centered at $16^{\circ} \mathrm{N}$ was seen even at greater depths.

The vertical salinity structure showed an isohaline layer of about $30 \mathrm{~m}$ thickness having a salinity of about 33 , except between $16^{\circ}$ and $17^{\circ} \mathrm{N}$, and south of $9^{\circ} \mathrm{N}$ (Fig.8b). In the former, salinity was 0.5 fresher, while in the latter salinity showed a steady increase. The halocline was located between 30 and $100 \mathrm{~m}$ depth, within which salinity increased north of $9^{\circ} \mathrm{N}$ by 1.5 . In the south, however, the gradient in the vertical salinity showed a steady decrease. Below $100 \mathrm{~m}$ salinity showed only small variation. The isohalines in the upper $100 \mathrm{~m}$ showed upward/downward sloping centered at $11^{\circ} \mathrm{N}$, $16^{\circ} \mathrm{N}$ and $19^{\circ} \mathrm{N}$.

The density (sigma-t) structure, in general, showed a weaker stratification in the upper $50 \mathrm{~m}$ with a thicker isopycnal layer north of $14^{\circ} \mathrm{N}$ compared to south (Fig.8c). The pycnocline was confined between 50 and $200 \mathrm{~m}$, within which there was marked upward/downward sloping of isopycnals centered at $11^{\circ}, 16^{\circ}$, and $19^{\circ} \mathrm{N}$. Consistent with temperature and salinity structures, the vertical displacements of isopycnals were largest centered at $19^{\circ} \mathrm{N}$.

Along the western margin the thermal structure showed a comparatively deep isothermal layer south of $16^{\circ} \mathrm{N}$ with a thickness of about $40 \mathrm{~m}$ and temperature in excess of $30^{\circ} \mathrm{C}$ (Fig. 9a). Towards the north the isothermal 
layer was thin, about $10 \mathrm{~m}$, and the temperature of this layer was about $1^{\circ} \mathrm{C}$ colder. In general, the isotherms in the upper thermocline showed a northward shoaling with the $29^{\circ} \mathrm{C}$ isotherm located at about $70 \mathrm{~m}$ deep in the south, which shoaled to about $10 \mathrm{~m}$ in the north. The most prominent feature was the upward/downward sloping of isotherms centered at $14^{\circ} \mathrm{N}$ and $17.5^{\circ} \mathrm{N}$, the latter being the most pronounced. The amplitude of isotherm displacement, though seen towards the deeper layers in both the cases, was greater at $14^{\circ} \mathrm{N}$. For example, at $14^{\circ} \mathrm{N}$, the $22^{\circ} \mathrm{C}$ isotherm shoaled by about 30 $\mathrm{m}$, while at $17.5^{\circ} \mathrm{N}$ it shoaled by about $70 \mathrm{~m}$. In contrast, in the deeper layers the $10^{\circ} \mathrm{C}$ isotherm showed a shoaling of about $140 \mathrm{~m}$, whereas it shoaled only by $40 \mathrm{~m}$ at $17.5^{\circ} \mathrm{N}$. The vertical displacement of isotherms at $100 \mathrm{~m}$ resulted in a depressing of the temperature by about $3^{\circ} \mathrm{C}$ at $14^{\circ} \mathrm{N}$ and by about and $5^{\circ} \mathrm{C}$ at $17.5^{\circ} \mathrm{N}$.

The vertical salinity structure also showed a gradual shoaling of isohalines from south towards north in the upper $100 \mathrm{~m}$, with surface waters north of $15^{\circ} \mathrm{N}$ fresher by 0.5 (Fig.9b). Accordingly, the vertical gradient of salinity in the upper $100 \mathrm{~m}$ was only 0.5 in the south, but it was 1 in the north. Consistent with the thermal structure, salinity distribution showed prominent isohaline displacements centered at $14^{\circ} \mathrm{N}$ and $17.5^{\circ} \mathrm{N}$.

The density (sigma-t) distribution essentially reflected the features in thermohaline structure (Fig.9c).

\subsubsection{Geostrophic currents}

The geostrophic velocities computed from the hydrographic data during spring intermonsoon also showed alternate bands of positive (eastward) and negative (westward) flows along both the central Bay and the western boundary transects (Fig.10). Along the central Bay transect flow was 
westward from $7^{\circ} \mathrm{N}$ to $13^{\circ} \mathrm{N}$, except for a weak $(\sim 10 \mathrm{~cm} / \mathrm{s})$ and shallow eastward flow centered at $10.5^{\circ} \mathrm{N}$ (Fig.10a). The maximum westward flow of $25 \mathrm{~cm} / \mathrm{s}$ was encountered at $12^{\circ} \mathrm{N}$. The westward flow reverses to eastward flow from $13^{\circ} \mathrm{N}$ to $16^{\circ} \mathrm{N}$ and had an average speed of about $10 \mathrm{~cm} / \mathrm{s}$. Once again the flow reverses to westward between $16^{\circ}$ and $18^{\circ} \mathrm{N}$ and then to an eastward flow north of $18^{\circ} \mathrm{N}$. In general, the strongest flow was encountered north of $16^{\circ} \mathrm{N}$ with the core of the westward flow (speed $35 \mathrm{~cm} / \mathrm{s}$ ) centered at $17^{\circ} \mathrm{N}$, while that of the eastward flow (speed $50 \mathrm{~cm} / \mathrm{s}$ ) was centered at $19^{\circ} \mathrm{N}$.

Along the western boundary, the flow was eastward south of $14^{\circ} \mathrm{N}$ with a maximum speed of $30 \mathrm{~cm} / \mathrm{s}$ followed by a stronger but narrower westward flow between 14 and $15.5^{\circ} \mathrm{N}$ with peak speed of $40 \mathrm{~cm} / \mathrm{s}$ (Fig.10b). Once again eastward and westward flows were encountered at the southern and northern side of $18^{\circ} \mathrm{N}$ respectively. The westward currents, however, were much weaker $(\sim 10 \mathrm{~cm} / \mathrm{s})$ in the latter case and confined to the upper $60 \mathrm{~m}$.

Thus, the opposing flows and the doming-structure in the thermohaline distribution appear to be the signature of a cold-core eddy. To confirm this, we analyzed the 7-day sea-level anomaly maps during 16 April to 13 May 2003. Since the CTD measurements along the central Bay track were carried out during 16 to 26 April 2003, the left panel in Fig. 12 represents conditions that prevailed in the central Bay sampling period, while the right panel represents the conditions during the sampling along western boundary, which was from 27 April to 5 May 2003. The sea-level anomaly picture showed the presence of three cyclonic eddies along the central Bay transect centered at $11^{\circ} \mathrm{N}, 90^{\circ} \mathrm{E}, 16^{\circ} \mathrm{N}, 89^{\circ} \mathrm{E}$, and $19^{\circ} \mathrm{N}, 90^{\circ} \mathrm{E}$ (Fig. $11 \mathrm{a}$ ). The cyclonic eddy in the north (centered at $19^{\circ} \mathrm{N}, 90^{\circ} \mathrm{E}$ ) was the most intense one, with a negative sea-level anomaly of about $22 \mathrm{~cm}$, followed by the one centered at 
$16^{\circ} \mathrm{N}, 89^{\circ} \mathrm{E}$, with a negative sea-level anomaly of $18 \mathrm{~cm}$. The southern one (centered at $11^{\circ} \mathrm{N}, 90^{\circ} \mathrm{E}$ ) was the least intense, with a negative sea-level anomaly of $6 \mathrm{~cm}$. None of the CTD stations sampled the eddy at its center. The eddy at $11^{\circ} \mathrm{N}$ was sampled far from its center causing its signature by way of upward/downward sloping of isopleths in the thermohaline structure (Fig.8) to be the least. Note the presence of an anticyclonic eddy at $18^{\circ} \mathrm{N}$, $87^{\circ} \mathrm{E}$ (Fig.11a), the effect of which is seen as the steep dip in the isotherms at $18^{\circ} \mathrm{N}$ (Fig.8). Along the western boundary also we see two cyclonic eddies, centered at $14^{\circ} \mathrm{N}$ and $17.5^{\circ} \mathrm{N}$, with negative sea-level anomalies of 22 and 18 $\mathrm{cm}$ respectively (Fig.11b) which were sampled by CTD stations close to their centers. Thus, we find five cyclonic eddies, three close to the openocean track and two along the western boundary, in the sea-level anomaly maps, which were sampled by the CTD stations during spring intermonsoon 2003.

\subsubsection{Nutrients}

Along the central Bay transect noticeable features of the vertical distribution of nitrate were that the concentrations in the upper $30 \mathrm{~m}$ below detection level and the oscillations within the nitracline (Fig.12a). Doming of isopleths was found prominently at 4 locations, centered at $9^{\circ} \mathrm{N}, 12^{\circ} \mathrm{N}$, $15^{\circ} \mathrm{N}$, and $19^{\circ} \mathrm{N}$. This resulted in appreciable enhancement of nitrate in the upper $50 \mathrm{~m}$ at these locations. For example, the $1-\mu \mathrm{M}$ isopleth, which was in general located below $50 \mathrm{~m}$, shoaled to about $25 \mathrm{~m}$ in the north under the influence of doming. Though a similar pattern of isopleth doming was observed in the distribution of silicate (Fig.12b), the concentrations in the upper $50 \mathrm{~m}$, unlike those of nitrate, did not vary much. This is primarily due to the greater ambient concentration in the upper $30 \mathrm{~m}$ of the water column, 
which was in the range $1.5-2 \mu \mathrm{M}$. The region of isopleth doming generally coincided with that of isotherms (Fig.8a), except that centered at $9^{\circ} \mathrm{N}$. However, from the sea-level anomaly map (Fig.11a) it can be seen that the CTD station at $9^{\circ} \mathrm{N}$ along the central Bay transect falls at the edge of a large cyclonic circulation feature at $2^{\circ}-8^{\circ} \mathrm{N}$ and $84^{\circ}-96^{\circ} \mathrm{E}$, which encompasses two cyclonic eddies (not sampled by CTD stations).

Along the western margin a prominent feature of both nitrate (Fig.12c) and silicate (Fig.12d) distribution was doming of isopleths centered between 17 and $18^{\circ} \mathrm{N}$. Under the influence of this doming, the $1-\mu \mathrm{M}$ nitrate and $2-\mu \mathrm{M}$ silicate isopleths, which were generally located at about $60 \mathrm{~m}$ depth, shoaled to shallower than $10 \mathrm{~m}$ and $20 \mathrm{~m}$ respectively (Fig.12c \& d). A minor doming was centered at $14^{\circ} \mathrm{N}$, in both the nitrate and the silicate distribution (Fig.12). As in the case of the central Bay, the nitrate levels in the upper 30 $\mathrm{m}$ were below detection except in the region of doming (Fig.12c). The silicate levels in the upper $30 \mathrm{~m}$ varied from 1.5 to $2 \mu \mathrm{M}$ (Fig.12d).

\subsubsection{Chlorophyll $a$ and primary productivity}

Along the central Bay transect, the vertical distribution of chlorophyll $a$ in the top $120 \mathrm{~m}$ showed that the surface concentration varied from 0.06 to $0.12 \mathrm{mg} / \mathrm{m}^{3}$ (Fig.7c). The most prominent features were the subsurface chlorophyll maximum (SCM) and enhanced chlorophyll $a$ concentrations between $18^{\circ}$ and $20^{\circ} \mathrm{N}$. The SCM was generally located between $60 \mathrm{~m}$ and $80 \mathrm{~m}$, depth where concentrations were in excess of $0.25 \mathrm{mg} / \mathrm{m}^{3}$. Under the influence of the eddy between $18^{\circ}$ and $20^{\circ} \mathrm{N}$ not only is the SCM pushed upward but also the chlorophyll concentrations within increase to 0.65 $\mathrm{mg} / \mathrm{m}^{3}$. Surface primary production (PP) varied from 0.01 to $3.97 \mathrm{mg} \mathrm{C} \mathrm{m}^{-3}$ 
$\mathrm{d}^{-1}$, while column-integrated PP (to $120 \mathrm{~m}$ ) ranged from 155 to $427 \mathrm{mg} \mathrm{C} \mathrm{m}^{-}$

${ }^{2} \mathrm{~d}^{-1}$ (Table 1). The higher value of column-integrated PP occurred in the eddy region in the north, where it was twotimes higher than it was in the non-eddy region.

Along the western boundary, surface chlorophyll $a$ varied from 0.06 to $0.21 \mathrm{mg} / \mathrm{m}^{3}$ and was, in general, higher than the open ocean values. But as in the case of the central Bay, the higher values were encountered towards the north (Fig. 7d). Here again we see enhanced chlorophyll $a$ concentrations of about $0.6 \mathrm{mg} / \mathrm{m}^{3}$ under the influence of the eddy near $17^{\circ} \mathrm{N}$. Surface PP varied from 1.87 to $9.68 \mathrm{mg} \mathrm{C} \mathrm{m}^{-3} \mathrm{~d}^{-1}$ and column-integrated PP from 250 to $469 \mathrm{mg} \mathrm{C} \mathrm{m}^{-2} \mathrm{~d}^{-1}$ (Table 1).

\section{Discussion and conclusion}

The thermohaline structures obtained from the in situ hydrographic measurements clearly indicated the presence of cyclonic eddies by way of doming isopleths/thermocline oscillation, both in the open Bay of Bengal and along the western boundary during both fall (2002) and spring (2003) intermonsoons. The spatial dimension of the thermocline oscillations associated with eddy ranged from 200 to $300 \mathrm{~km}$, which means that at the most 3 stations sampled the eddy region. The rotary flows associated with these eddies were seen as alternate bands of reversing zonal currents in the geostrophic computations. In fact, the currents showed cyclonic circulation with eastward flow in the region of upward sloping isopleths and westward flow coinciding with downward sloping isopleths. Satellite-derived sea-level anomaly maps showed 4 distinct cyclonic eddies, 2 each along the central Bay and along western boundary respectively, during fall intermonsoon 
2002 and 5 cyclonic eddies during spring intermonsoon, of which 3 were along the central Bay transect and 2 along the western boundary. The sealevel anomaly maps revealed that the eddy generated during the spring intermonsoon had a life span of about 5 months, while that during the fall intermonsoon was short lived.

In the fall intermonsoon, these eddies depressed the ambient temperature by about $3^{\circ} \mathrm{C}$ in the upper $120 \mathrm{~m}$ in all the cases except at $18^{\circ} \mathrm{N}$ along the western boundary, where the temperature drop was about $5^{\circ} \mathrm{C}$. To explore the reason for such differential cooling, we computed the static stability parameter (E) (Pond and Pickard, 1978) during fall intermonsoon. A comparison of the profiles at $18^{\circ} \mathrm{N}, 84.5^{\circ} \mathrm{E}$ and $14^{\circ} \mathrm{N}, 88^{\circ} \mathrm{E}$ (Fig. $13 \mathrm{a}$ ) clearly showed that though the water column in the upper $40 \mathrm{~m}$ at $18^{\circ} \mathrm{N}$ was much more strongly stratified than that at $14^{\circ} \mathrm{N}$, below this depth and down to 160 $\mathrm{m}$ the water column at $18^{\circ} \mathrm{N}$ was much less stable, which helped the cyclonic eddy at this location to pump more cold water to the top layers. However, the low-salinity surface waters, especially in the north, induced a strong halocline in the upper $50 \mathrm{~m}$ of the water column. The observed very low surface salinity of 29 in the open Bay and 25 near the western boundary in the north indicated the strong influence of fresh water flux due to the large E-P, which is in excess of $200 \mathrm{~mm} / \mathrm{month}$ during June to August (see Fig.9 of Narvekar and Prasanna Kumar, 2006). In addition to the oceanic precipitation there is also a large amount of freshwater input from peninsular rivers. The monthly mean climatology of river discharge of the 6 major rivers Ganges, Brahmaputra, Irrawady, Godavari Krishna, and Cauvery, obtained from Global Runoff Data Center, Germany (http://grdc.bafg.de/servlet/is/2781/), showed that the freshwater discharge dominated during July to October (Fig.14a). The cumulative discharge of 
these 6 rivers during this period (Fig.14b) amounted to a voluminous $3.46 \mathrm{x}$ $10^{12} \mathrm{~m}^{3}$. Note that the precipitation peaks in July (Fig.9 of Narvekar and Prasanna Kumar, 2006), while the river discharge peaks in August (Fig.14a). So there is a time lag between the precipitation and the freshwater discharge peaks.

Thus, though the cyclonic circulation associated with the eddy is capable of pumping cold subsurface waters towards surface as seen from the doming isopleths, the strong stratification associated with the low-salinity waters inhibited the shoaling of isopleths to the surface, thereby capping the eddy signature below $20 \mathrm{~m}$ from the surface.

In the spring intermonsoon also these eddies depressed the temperature by $3^{\circ} \mathrm{C}$ at $120 \mathrm{~m}$ in all the cases except at $19^{\circ} \mathrm{N}$ in the central Bay and $17.5^{\circ} \mathrm{N}$ along the western boundary, where the cooling was $7^{\circ} \mathrm{C}$ and $5^{\circ} \mathrm{C}$, respectively. Here again, the stability profiles showed that at $19^{\circ} \mathrm{N}$, where the cooling was the highest, the water column below $80 \mathrm{~m}$ depth was much less stable compared to other eddy locations, for example at $14^{\circ} \mathrm{N}$ (Fig.13b). But unlike the fall intermonsoon, surface salinity during spring intermonsoon was much higher, with lowest values of 32.5 along the central Bay and 33 along the western boundary towards the north. This high surface salinity arises from positive E-P, which is in excess of $40 \mathrm{~mm} / \mathrm{month}$ (Fig.9 of Narvekar and Prasanna Kumar, 2006) coupled with marginal river discharge during spring intermonsoon (Fig.14a). SST during spring intermonsoon along the central Bay transect was $1^{\circ} \mathrm{C}$ warmer in the north, but towards the south it was $2^{\circ} \mathrm{C}$ warmer. However, along the western boundary SST remained similar in both seasons. Though the warm SST in spring intermonsoon is capable of stratifying the upper ocean, the higher surface salinity in spring than in fall intermonsoon could counteract this, as 
can be seen from the stability profiles (note the break in scale during fall intermonsoon).

As mentioned earlier, these cold-core eddies are capable of pumping subsurface waters to the upper layers. Eddy-pumping could cause an upward displacement of the nutricline along constant density surfaces and inject growth-limiting macro- (such as nitrate, phosphate and silicate) and micro(such as iron) nutrients to an impoverished euphotic zone (Falkowski et al., 1991; Olaizola et al., 1993; McGillicuddy and Robinson, 1997; McGillicuddy et al., 1998; Seki et al., 2001). If there is enough sunlight this will lead to enhanced rates of biological productivity and export out of the euphotic zone. We see enhanced levels of nitrate and silicate during both fall and spring intermonsoons in the region of eddies. The observed co-located high concentrations of chlorophyll $a$ during fall and spring intermonsoons are the response of nutrient injection into the euphotic zone by these eddies. Eddy-pumping of nutrients increased the chlorophyll $a$ concentrations to more than $1 \frac{1}{2}$ times. Another effect of eddy pumping is that the subsurface chlorophyll maximum (SCM), which is generally located between 40 and 70 $\mathrm{m}$, is pushed upward. In fact, in spring intermonsoon SCM is even deeper, between 60 and $90 \mathrm{~m}$, and the eddy-pumping not only shallows the SCM but increases the chlorophyll $a$ in the SCM to more than double. In an earlier study Murty et al. (2000) reported the depth of the SCM in the open-sea region of the Bay of Bengal between 50 and 100 m based on May-June 1996 measurements. However, their chlorophyll $a$ concentrations were extremely low compared to earlier measurements (Radhakrishna et al., 1982, Devassy et al., 1983; Sarma and Kumar, 1991; Prasanna Kumar et al., 2002; Madhupratap et al., 2003), especially in the SCM, where they were $\sim 0.1$ $\mathrm{mg} / \mathrm{m}^{3}$. 
Apart from the nutrient enhancement in the eddy region, we also note enhancement of nitrate and silicate in the surface layer along the western boundary during fall intermonsoon towards $20^{\circ} \mathrm{N}$ and $11^{\circ} \mathrm{N}$ (see 0.5 - and $1.5-\mu \mathrm{M}$ contours in Fig. $6 \mathrm{c} \& \mathrm{~d}$ respectively). In the case of silicate the surface concentrations in the north were as high as $15 \mu \mathrm{M}$. This indicated that the nutrient source in the north must be the river input. As the river discharge peaks during August (Fig.14a), it is quite likely that the surface enhancement of nutrients brought by river influx will be felt in the fall intermonsoon. Since the surface circulation at this time of the year is southward from the head of the Bay along the western boundary (Fig.5), there are more chances for the nutrients brought by the river input to be advected along the western boundary than in the offshore region. Hence, we see this signal as enhanced nutrients in the northern part of the western boundary rather than in the northern part of the open-ocean transect. Consistent with this the chlorophyll $a$ in the upper $30 \mathrm{~m}$ in northern part of the western boundary was $0.4 \mathrm{mg} / \mathrm{m}^{3}$, while it was only $0.15 \mathrm{mg} / \mathrm{m}^{3}$ in the northern part of the open-ocean transect. Again, in the south $\left(11^{\circ} \mathrm{N}\right)$ the runoff from southern rivers could explain the enhanced levels of nutrients and associated elevated chlorophyll.

Eddies enhanced the biological productivity by more than $1 \frac{1}{2}$ times during both fall and spring intermonsoons. Interestingly, during fall intermonsoon the column-integrated biological productivity in the north was about $2 \frac{1}{2}$ times less than that in the south along the open ocean transect. In contrast, along the western boundary the northern part was about $1 \frac{1}{2}$ times more productive than the south. This low biological productivity in the north along the central Bay transect, in spite of nutrient availability in the upper water column, points to the possibility of light limitation due to the 
suspended sediment load brought in by the river runoff. Along the northern part of the western boundary, however, the quantity of nutrient in the surface layer is more than that in the northern part of the open-ocean transect. Note that along the western boundary the surface productivity in the north is more than 7 times that in the south (Table 1). Hence, though there could be light limitation in the northern part of the western boundary, comparatively high nutrient levels in the upper layer leads to an overall high productivity in comparison to the south. During spring intermonsoon, however, the enhanced biological productivity is entirely controlled by eddy-pumping of nutrients to the euphotic zone.

It is now evident that cyclonic eddies exist and enhance biological productivity of the Bay of Bengal, not only in summer monsoon (Prasanna Kumar et al., 2004) but also in fall and spring intermonsoons. Though the surface chlorophyll concentrations as detected by satellite remote sensing may be perennially low, these cyclonic eddies, which appear to be ubiquitous in the Bay of Bengal, enhance biological productivity by $1 \frac{1}{2}-2$ times its ambient value through eddy-pumping of nutrients. This has an overall implication for the basin-wide new production and export flux. The comparable rates of the annual fluxes of organic carbon between the highproductivity Arabian Sea and what has traditionally been considered to be the low-productivity Bay of Bengal could be, at least in part, explained by enhancement of biological productivity in the Bay of Bengal by cyclonic eddies. However, we need more eddy-targeted measurements and modeling efforts to quantify the impact of the eddies on the biological pump in the Bay of Bengal. 


\section{Acknowledgements}

This study forms a part of the national programme Bay of Bengal Process

Studies (BOBPS) funded by Department of Ocean Development (DOD), New Delhi. We are thankful to all the participants of ORV Sagar Kanya cruises SK 182 and 191, especially to P.M. Muraleedharan, G.

Nampoothitiri, R. Jyotibabu and K. Jayaraj for help in data collection. This is NIO contribution number 4271.

\section{References}

Babu, M.T., Prasanna Kumar, S., Rao, D.P., 1991. A subsurface cyclonic eddy in the Bay of Bengal. Journal of Marine Research 49, 404-410.

Babu, M.T., Sarma, Y.V.B., Murty, V.S.N., Vethamony, P., 2003. On the circulation in the Bay of Bengal during northern spring inter-monsoon (March-April) 1987. Deep-Sea Research II 50, 855-865.

Devassy, V.P., Bhattathiri, P.M.A., Radhakrishna, K., 1983. Primary production in the Bay of Bengal during August, 1997. Mahasagar-Bulletin of National Institute of Oceanography 16, 443-447.

Falkowski, P.G., Ziemann, D., Kolber, Z., Bienfang, P.K., Role of eddy pumping in enhancing primary production in the ocean. Nature 352, 55-58. Gomes, H.R., Goes, J.I., Saino, T., 2000. Influence of physical processes and freshwater discharge on the seasonality of phytoplankton regime in the Bay of Bengal. Continental Shelf Research 20, 313-330.

Legeckis, R., 1987. Satellite observations of a western boundary current in the Bay of Bengal. Journal of Geophysical Research 92, 12974-12978.

Levitus, S., Gelfeld, R., Boyer, T., Johnson, D., 1994. Results of the NODC Oceanographic Data Archaeology and Rescue Projects, Key to Oceanograhic Records Documentation No. 19, NODC, Washington, D.C., $73 p p$.

Madhusoodhanan, P., James, V.V., 2003. Thermohaline features of the subsurface cyclonic eddy in the south central Bay of Bengal during August 1999. Proceedings of the Indian Academy of Sciences (Earth and Planetary Sciences) 112, 233-23.

Madhupratap, M., Mangesh Gauns, Ramaiaha, N., Prasanna Kumar, S., 
Muraleedharan, P.M., De Sousa, S.N., Sardessai, S., Usha Muraleedharan, 2003. Biogeochemistry of the Bay of Bengal: physical, chemical and primary productivity characteristics of the central and western Bay of Bengal during summer monsoon 2001. Deep-Sea Research II 50, 881-896. McGillicuddy, D.J., Robinson, A.R., 1997. Eddy induced nutrient supply and new production in the Sargasso Sea. Deep-Sea esearch I 44, 14271449.

McGillicuddy, D.J., Robinson, A.R., Siegel, D.A., Jannasch, H.W., Johnson, R., Dickey, T.D., McNeil, J., Michaels, A.F., Knap, A.H., 1998. Influence of mesoscale eddies on new production in the Sargaso Sea. Nature 394, 263-266.

Murty, C.S., Varadachari, V.V.R., 1968. Upwelling along the east coast of India. Bulletin of National Institute of Science India 36, 80-86.

Murty, V.S.N., A. Suryanarayana, Rao, D.P., 1993. Current structure and volume transport across $12^{\circ} \mathrm{N}$ in the Bay of Bengal. Indian Journal of Marine Sciences 22, 12-16.

Murty, V.S.N., G.V.M. Gupta, V.V. Sarma, B.P. Rao, D. Jyothi, P.N.M. Shastri, Supraveena, Y., 2000. Effect of vertical stability and circulation on the depth of the chlorophyll maximum in the Bay of Bengal during May-June 1996. Deep-Sea Research I 47, 859-873.

Narvekar, J., Prasanna Kumar, S., 2006. Seasonal variability of he mixed layer in the central Bay of Bengal and associated changes in nutrient and chlorophyll. Deep-Sea Research I 53, 820-835.

Olaizola, M., Ziemann, D.A., Bienfang, P.K., Walsh, W.A., Conquest, L.D., 1993. Eddy-induced oscillations of the phycnocline affect the floristic composition and depth distribution of phytoplankton in the subtropical Pacific. Marine Biology 116, 533-542.

Pond, S., Pickard, G.L., 1978. Introductory dynamic oceanography. Pergamon Press, New York, 241pp.

Prasad, T.G., 1997. Annual and seasonal mean buoyancy fluxes for the tropical Indian Ocean. Current Science 73, 667-674.

Prasanna Kumar, S., Muraleedharan, P.M., Prasad, T.G., Gauns, M., Ramaiah, N., de Souza, S.N., Sardesai, D.S., Madhupratap, M., 2002. Why is the Bay of Bengal less productive during summer monsoon compared to the Arabian Sea?, Geophysical Research Letters, 29, 2235, doi:10.1029/ 2002 GL016013.

Prasanna Kumar, S., Nuncio, M., Jayu Narvekar, Ajoy Kumar, Sardesai, S., Desouza, S.N., Mangesh Gauns, Ramaiah, N. and Madhupratap, M., 2004. Are Eddies nature's trigger to enhance biological productivity in the Bay of Bengal?, Geophysical Research Letters, 31, L07309, doi:10..1029/ 


\section{$2003 \mathrm{G} 1019274$.}

Qasim, S.Z., 1977. Biological productivity of the Indian Ocean. Indian Journal of Marine Sciences 6, 122-137.

Radhakrishna, K., 1978. Primary productivity of the Bay of Bengal during March-April 1975, Indian Journal of Marine Sciences 7, 58-60.

Radhakrishna, K., Bhattathiri, P.M.A., Devassy, V.P., 1982. Chlorophyll-a, phaeopigments and particulate organic carbon in the northern and western Bay of Bengal. Indian Journal of Marine Sciences 11, 287-291.

Ramasastry. A.A., Balaramamurty, C., 1957. Thermal fields and oceanic circulation along the east coast of India, Proceedings of Indian Academy of Science 46, 293-323.

Ramaswamy, V., Nair, R.R., 1994. Fluxes of material in the Arabian Sea and Bay of Bengal - Sediment trap studies. Proceedings of the Indian Academy of Sciences (Earth and Planetary Sciences) 103, 189-210.

Rao, D.P.,. Sastry, J.S., 1981. Circulation and distribution of some hydrographical properties during the late winter in the Bay of Bengal, Mahasagar-Bulletin of National Institute of Oceanography 14, 1-16.

Sanilkumar, K.V., Kuruvilla, T.V., Jogendranath, D., Rao, R.R., 1997. Observation of the western boundary current of the Bay of Bengal, DeepSea Research I 44, 135-145.

Sarma, V.V., Kumar, V,.A., 1991. Subsurface chlorophyll maxima in the northwestern Bay of Bengal. Journal of Plankton Research 13, 339-352. Seki, M.P., Polovina, J.J., Brainard, R.E., Bidigare, R.R., Leonard, C.L., Foley, D.G., 2001. Biological enhancement at cyclonic eddies tracked with GOES thermal imagery in Hawaiian waters. Geophysical Letters 28, 1583-1586.

Sengupta, R., De Sousa, S.N., Joseph, T., 1977. On nitrogen and phosphorous in the western Bay of Bengal. Indian Journal of Marine Sciences 6, 107-110.

Shetye, S.R., Shenoi, S.S.C., Gouveia, A.D., Michael, G.S., Sundar, D., Nampoothiri, G., 1991. Wind-driven coastal upwelling along the western boundary of the Bay of Bengal during the southwest monsoon. Continental Shelf Research 11, 1397-1408.

Shetye, S.R, A.D. Gouveia, S.S.C. Shenoi, D. Sundar, G.S. Michael, G. Nampoothiri, 1993. The western boundary current of the seasonal subtropical gyre in the Bay of Bengal. Journal of Geophysical Research 98, 945-954.

Subramanian, V., 1993. Sediment load of Indian Rivers. Current Science 64, 928-930. 
UNESCO. 1994. Protocols for the Joint Global Ocean Flux Study (JGOFS). Manual and Guides 29, pp. 170. 


\section{Legends to figures}

Fig. 1 Location map showing the BOBPS sampling stations along central $\left(88^{\circ} \mathrm{E}\right)$ and western Bay of Bengal during fall (14 September - 12 October, 2002) and spring (12 April - 7 May, 2003) intermonsoons overlying on the annual mean surface salinity distribution (Levitus et al., 1994). Dark circles (•) indicate 1-degree CTD stations while hollow circles $(\odot)$ are the biological stations for in-situ incubation for primary production. Rivers Ganges-Brahmaputra, Godavari, Krishna, Cauvery and Irrawady are also shown. Depth contours are in meters.

Fig. 2. Vertical section of (a) temperature $\left({ }^{\circ} \mathrm{C}\right)$, (b) salinity, and (c) sigma-t $\left(\mathrm{kg} / \mathrm{m}^{3}\right)$ along the central Bay of Bengal $\left(88^{\circ} \mathrm{E}\right)$ during fall intermonsoon 2002. Filled inverted triangles $(\boldsymbol{\nabla})$ on the top indicate the locations of CTD stations. Note the change in salinity contour interval $<32$ in (b).

Fig. 3. Vertical section of (a) temperature $\left({ }^{\circ} \mathrm{C}\right)$, (b) salinity, and (c) sigma-t $\left(\mathrm{kg} / \mathrm{m}^{3}\right)$ along the western Bay of Bengal during fall intermonsoon 2002. Filled inverted triangles $(\boldsymbol{\nabla})$ on the top indicate the locations of CTD stations. Note the change in salinity contour interval $<32$ in (b).

Fig. 4. Vertical section of geostrophic velocity $(\mathrm{cm} / \mathrm{s})$ w.r.t. $1000 \mathrm{~m}$ along (a) central $\left(88^{\circ} \mathrm{E}\right)$ and (b) western boundary of the Bay of Bengal during fall intermonsoon 2002. Shading indicates westward flow while the flow in the rest of the region is eastward.

Fig.5 7-day snapshots of Topex/Poseidon ERS1/2 merged sea-level anomalies overlaid with geostrophic velocities during (a) 18-24 September 2002 and (b) 2-8 October 2002 falling within the period of CTD measurements along the central Bay (17-27 September 2002) and the western boundary (30 September to 11 October 2002) transects. Dark circles $(\bullet)$ indicate 1-degree CTD stations.

Fig. 6 Vertical section of (left) nitrate $\left(\mu \mathrm{mol} \mathrm{L}{ }^{-1}\right)(\mathrm{a}, \mathrm{c})$ and (right) silicate $\left(\mu \mathrm{mol} \mathrm{L}{ }^{-1}\right)(\mathrm{b}, \mathrm{d})$ along (top) the central Bay of Bengal $\left(88^{\circ} \mathrm{E}\right)(\mathrm{a}, \mathrm{b})$ and (bottom) the western boundary $(\mathrm{c}, \mathrm{d})$ during fall intermonsoon 2002. Zero (0) indicates concentration below detection level. Note the change in contour interval of dashed line, which is $0.5 \mu \mathrm{mol} \mathrm{L}{ }^{-1}$. Dark circles $(\bullet)$ indicate the sample locations.

Fig.7. Vertical distribution of chlorophyll $a\left(\mathrm{mg} / \mathrm{m}^{3}\right)$ along (left) the central Bay of Bengal $\left(88^{\circ} \mathrm{E}\right)(\mathrm{a}, \mathrm{c})$ and (right) the western boundary $(\mathrm{b}, \mathrm{d})$ during (top) fall intermonsoon 2002 (a,b) and (bottom) spring intermonsoon 2003 (c,d). Dark circles $(\bullet)$ indicate the sample locations. Note that the shading is removed for chlorophyll $a$ concentrations $<0.2 \mathrm{mg} / \mathrm{m}^{3}$ in $(\mathrm{a}, \mathrm{b})$ and for concentrations $>0.4$ $\mathrm{mg} / \mathrm{m}^{3}$ and $<0.2 \mathrm{mg} / \mathrm{m}^{3}$ in $(\mathrm{c}, \mathrm{d})$. 
Fig. 8. Vertical section of (a) temperature $\left({ }^{\circ} \mathrm{C}\right)$, (b) salinity, and (c) sigma-t $\left(\mathrm{kg} / \mathrm{m}^{3}\right)$ along the central Bay of Bengal $\left(88^{\circ} \mathrm{E}\right)$ during spring intermonsoon 2003. Filled inverted triangles $(\boldsymbol{\nabla})$ on the top indicate the locations of CTD stations.

Fig. 9. Vertical section of (a) temperature $\left({ }^{\circ} \mathrm{C}\right)$, (b) salinity, and (c) sigma-t $\left(\mathrm{kg} / \mathrm{m}^{3}\right)$ along the western Bay of Bengal during spring intermonsoon 2003. Filled inverted triangles $(\boldsymbol{\nabla})$ on the top indicate the locations of CTD stations.

Fig. 10. Vertical section of geostrophic velocity $(\mathrm{cm} / \mathrm{s})$ w.r.t. $1000 \mathrm{~m}$ along (a) central $\left(88^{\circ} \mathrm{E}\right.$ ) and (b) western boundary of the Bay of Bengal during spring intermonsoon 2003. Shading indicates westward flow, while the flow in the rest of the region is eastward.

Fig.11. 7-day snapshots of Topex/Poseidon ERS1/2 merged sea-level anomalies overlaid with geostrophic velocities during (a) 16-22 April 2003 and (b) 30 April-6 May 2003 falling within the period of CTD measurements along the central (16-26 April 2003) and the western boundary (27 April to 5 May 2003) transects. Dark circles $(\bullet)$ indicate 1 -degree CTD stations.

Fig. 12. Vertical section of (left) nitrate $\left(\mu \mathrm{mol} \mathrm{L} \mathrm{L}^{-1}\right)(\mathrm{a}, \mathrm{c})$ and (right) silicate $\left(\mu \mathrm{mol} \mathrm{L} \mathrm{L}^{-1}\right)$ $(\mathrm{b}, \mathrm{d})$ along (top) the central Bay of Bengal $\left(88^{\circ} \mathrm{E}\right)(\mathrm{a}, \mathrm{b})$ and (bottom) the western boundary $(\mathrm{c}, \mathrm{d})$ during spring intermonsoon 2003. Zero (0) indicates concentration below detection level. Note the change in contour interval of dashed line, which is $0.5 \mu \mathrm{mol} \mathrm{L}{ }^{-1}$. Dark circles $(\bullet)$ indicate the sample locations.

Fig.13 Profiles of upper ocean static stability parameter $\left(\mathrm{E}, \mathrm{m}^{-1}\right)$ at (a) $18^{\circ} \mathrm{N}, 84.5^{\circ} \mathrm{E}$ and $14^{\circ} \mathrm{N}, 88^{\circ} \mathrm{E}$ during fall intermonsoon 2002 and (b) $19^{\circ} \mathrm{N}, 88^{\circ} \mathrm{E}$ and $14^{\circ} \mathrm{N}, 81^{\circ} \mathrm{E}$ during spring intermonsoon 2003.

Fig.14 Climatology of (a) monthly mean river discharge $\left(\mathrm{m}^{3} / \mathrm{s}\right)$ and (b) the cumulative discharge $\left(\mathrm{m}^{3}\right)$ during July to October of rivers Ganges, Brahmaputra, Irrawady, Godavari, Krishna, and Cauvery. The river discharge data was obtained from Global Runoff Data Center, Germany (http://grdc.bafg.de/servlet/is/2781/). 
Table 1. Surface $\left(\mathrm{mg} \mathrm{C} \mathrm{m} \mathrm{m}^{-3}\right)$ and column-integrated $\left(\mathrm{mg} \mathrm{C} \mathrm{m} \mathrm{m}^{-2} \mathrm{~d}^{-1}\right)$ primary production (PP) along the central and western boundary transects of the Bay of Bengal. Integration is down to $120 \mathrm{~m}$ of the water column from surface.

\begin{tabular}{|c|c|c|c|c|c|}
\hline \multirow{2}{*}{\multicolumn{2}{|c|}{ Latitude (N) }} & \multicolumn{2}{|c|}{ Fall intermonsoon 2002} & \multicolumn{2}{|c|}{ Spring intermonsoon 2003} \\
\hline & & \multirow{2}{*}{$\begin{array}{r}\begin{array}{l}\text { Surface PP } \\
\mathrm{mg} \mathrm{C} \mathrm{m}^{-3} \mathrm{~d}^{-1}\end{array} \\
17.7 \pm 2.7\end{array}$} & \multirow{2}{*}{$\begin{array}{c}\begin{array}{l}\text { Integrated PP } \\
\mathrm{mg} \mathrm{C} \mathrm{m}^{-2} \mathrm{~d}^{-1}\end{array} \\
513 \pm 30\end{array}$} & \multirow{2}{*}{$\begin{array}{r}\begin{array}{l}\text { Surface PP } \\
\mathrm{mg} \mathrm{C} \mathrm{m}^{-3} \mathrm{~d}^{-1}\end{array} \\
0.01^{*} \pm 0.08\end{array}$} & \multirow{2}{*}{$\begin{array}{l}\frac{\begin{array}{l}\text { Integrated PP } \\
\mathrm{mg} \mathrm{C} \mathrm{m}^{-2} \mathrm{~d}^{-1}\end{array}}{204 \pm 18}\end{array}$} \\
\hline \multirow{5}{*}{ 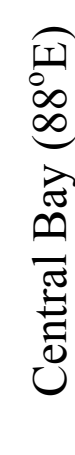 } & 9 & & & & \\
\hline & 12 & $5.3 \pm 0.8$ & $316 \pm 17$ & $3.2 \pm 0.5$ & $216 \pm 15$ \\
\hline & 15 & $9.3 \pm 3.6$ & $336 \pm 5$ & $4.0 \pm 0.9$ & $202 \pm 39$ \\
\hline & $18 / 17$ & $5.7 \pm 0.3$ & $182 \pm 15$ & $2.9 \pm 0.8$ & $155 \pm 20$ \\
\hline & 20 & $8.5 \pm 0.9$ & $184 \pm 48$ & $2.4 \pm 0.4$ & $427 \pm 40$ \\
\hline \multirow{4}{*}{ 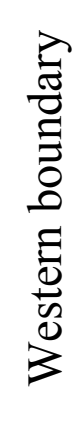 } & 12 & $6.2 \pm 0.5$ & $245 \pm 13$ & $2.7 \pm 0.2$ & $305 \pm 25$ \\
\hline & 15 & $3.2 \pm 1.5$ & $196 \pm 35$ & $1.9 \pm 0.9$ & $250 \pm 11$ \\
\hline & 17 & $25.4 \pm 8.1$ & $334 \pm 59$ & $5.6 \pm 3.0$ & $439 \pm 9$ \\
\hline & 19 & $45.2 \pm 0.7$ & $350 \pm 18$ & $9.7 \pm 1.0$ & $469 \pm 30$ \\
\hline
\end{tabular}

Note that the PP measurements along the central Bay $\left(88^{\circ} \mathrm{E}\right)$ during fall intermonsoon were at $18^{\circ} \mathrm{N}$ while those during spring intermonsoon were at $17^{\circ} \mathrm{N}$. ${ }^{*}$ The unusually low surface PP is inexplicable. However, at $10 \mathrm{~m}$ depth it was $2.88 \mathrm{mg} \mathrm{C} \mathrm{m}^{-2} \mathrm{~d}^{-1}$ though the chlorophyll $a$ was around $0.06 \mathrm{mg}$ $\mathrm{m}^{-3}$ at both depths. Mean $\pm \mathrm{SE}$ (standard error) was calculated using ${ }^{14} \mathrm{C}$ counts (disintegration per minute; dpm) of 3 light-bottles (triplicate sample). The dark bottle dpm was subtracted from each light-bottle dpm before calculating the mean $\pm \mathrm{SE}$. 


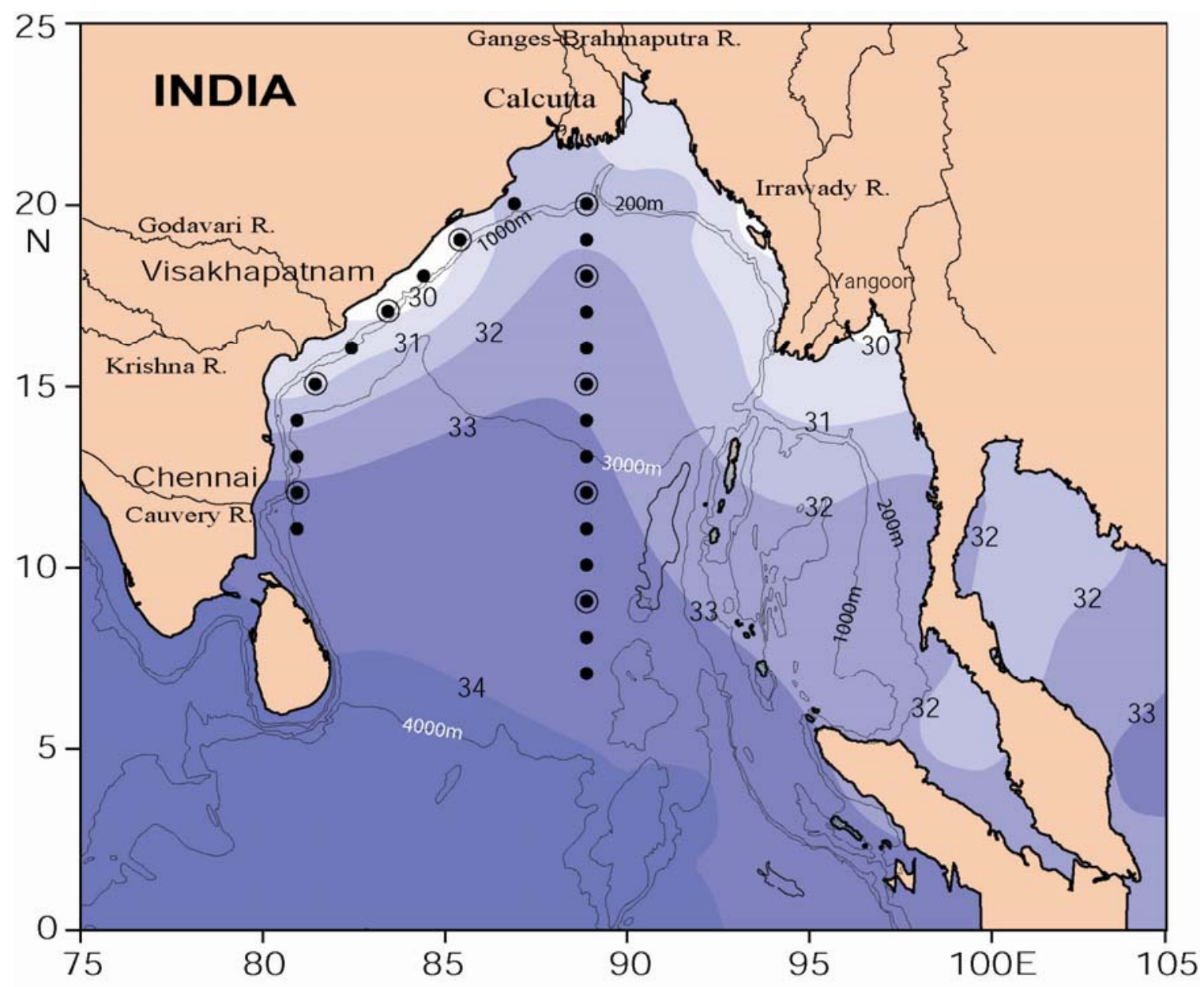

Fig.1 Location map showing the BOBPS sampling stations along central $\left(88^{\circ} \mathrm{E}\right)$ and western Bay of Bengal during fall (14 September -12 October, 2002) and spring (12 April - 7 May, 2003) intermonsoons overlying the annual mean surface salinity distribution (Levitus et al., 1994). Dark circles indicate 1-degree CTD stations while hollow circles are the biological stations for in-situ incubation for primary production. Rivers Ganges-Brahmaputra, Godavari, Krishna, Cauvery and Irrawady are also shown. Depth contours are in meters. 
(a)

(b)

(c)

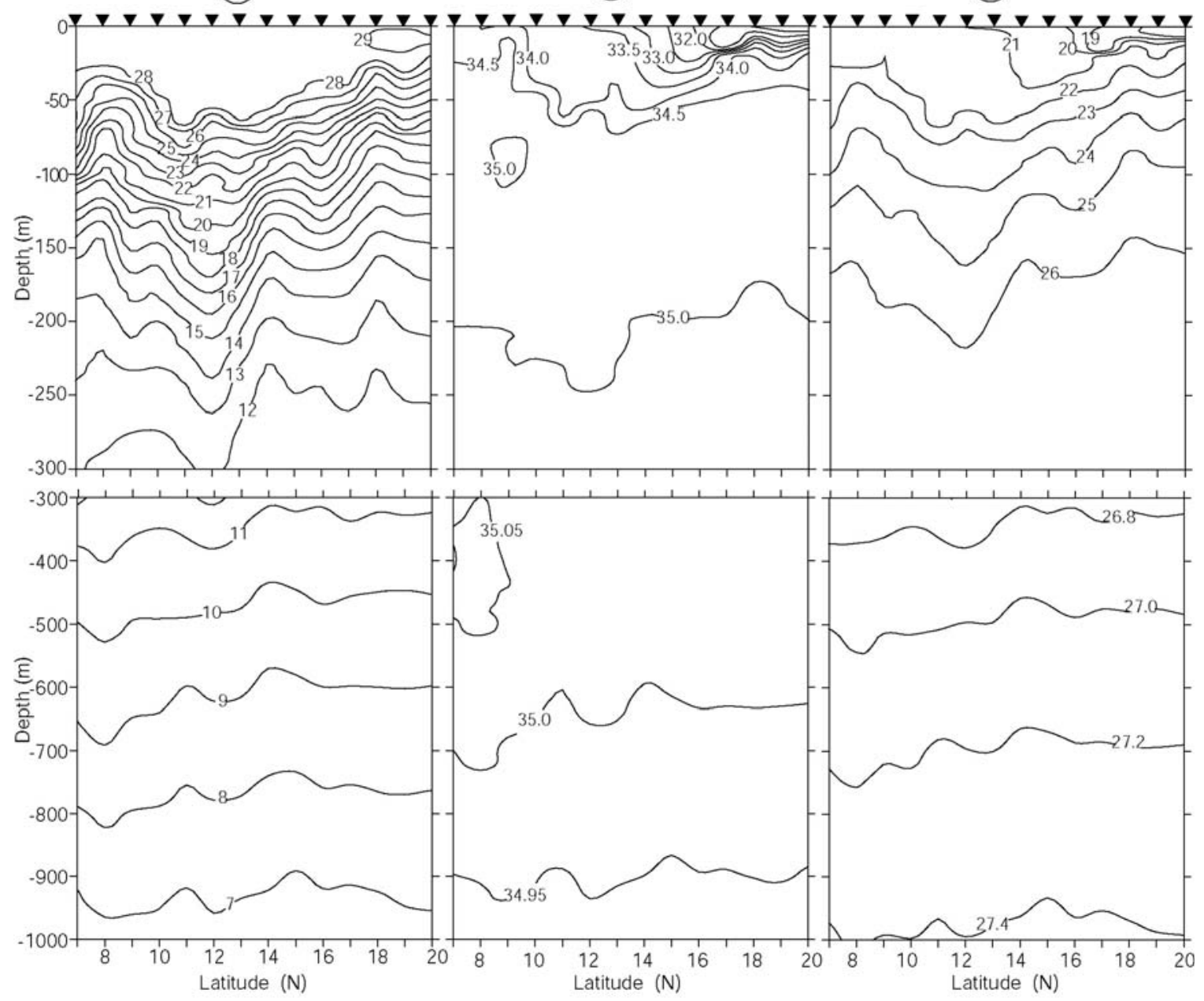

Fig.2 Vertical section of (a) temperature ( $\left.{ }^{\circ} \mathrm{C}\right)$, (b) salinity, and (c) sigma-t $\left(\mathrm{kg} / \mathrm{m}^{3}\right)$ along the central Bay of Bengal $\left(88^{\circ} \mathrm{E}\right)$ during fall intermonsoon 2002 . Filled inverted triangles $(\mathbf{v})$ indicate the location of CTD stations. Note the change in contour interval $<32$ in (b). 
(a)
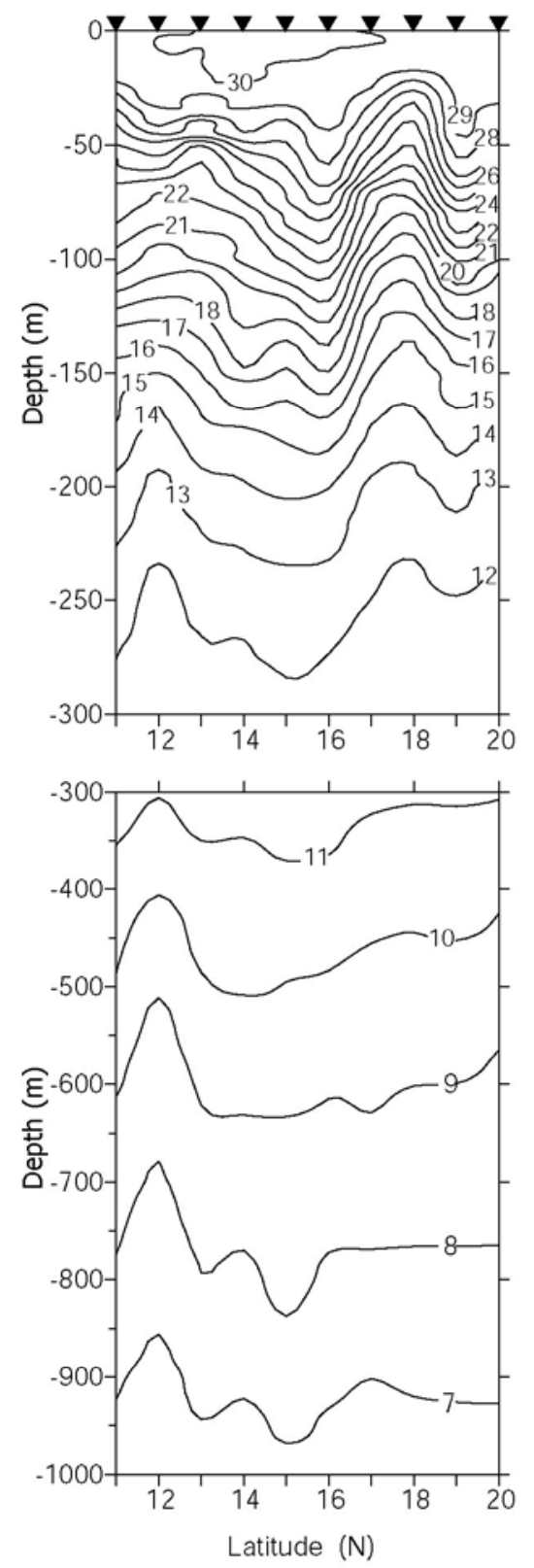

(b)
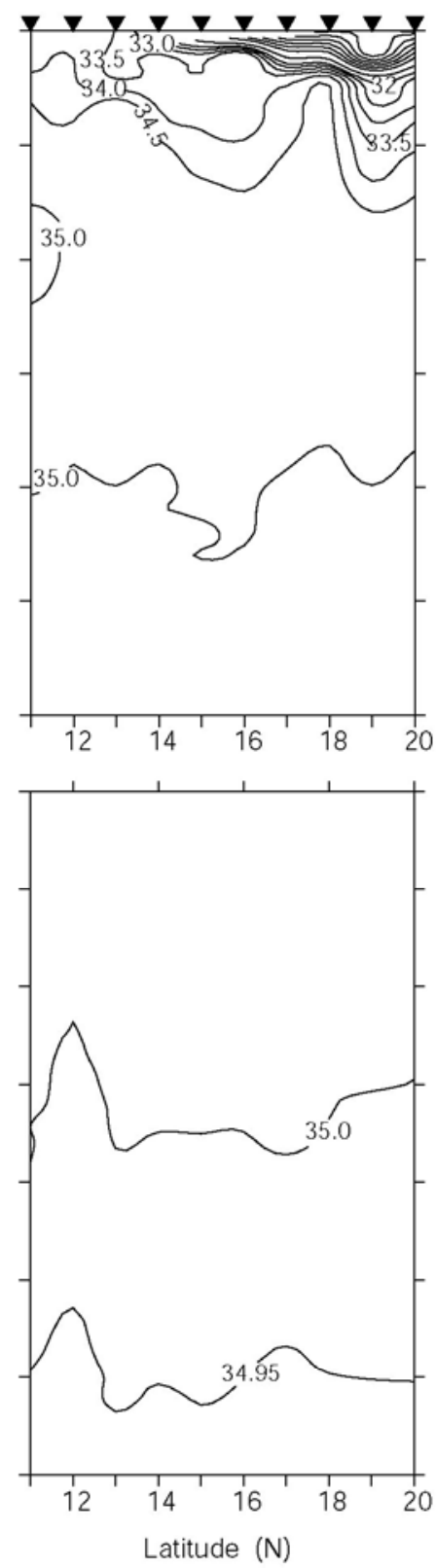

(c)
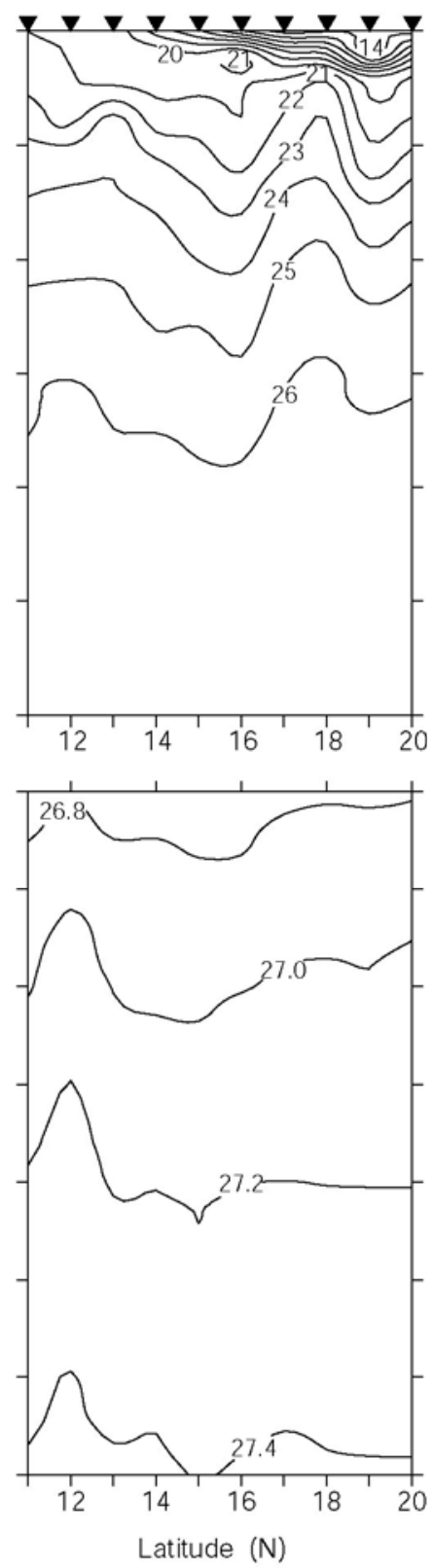

Fig. 3 Vertical section of (a) temperature $\left({ }^{\circ} \mathrm{C}\right)$, (b) salinity, and (c) sigma-t $\left(\mathrm{kg} / \mathrm{m}^{3}\right)$ along the western boundary of the Bay during fall intermonsoon 2002. Filled inverted triangles ( $\mathbf{v})$ indicate the location of CTD stations. Note the change in contour interval $<32$ in (b). 
(a)

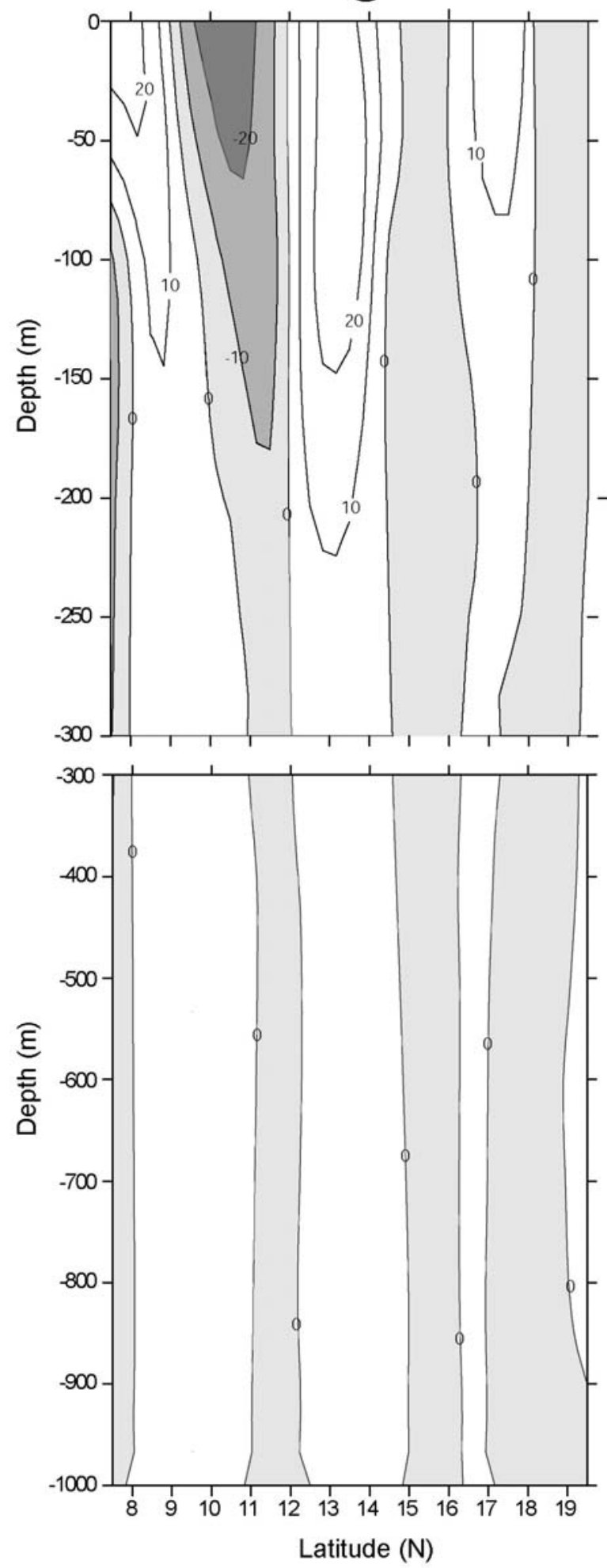

(b)
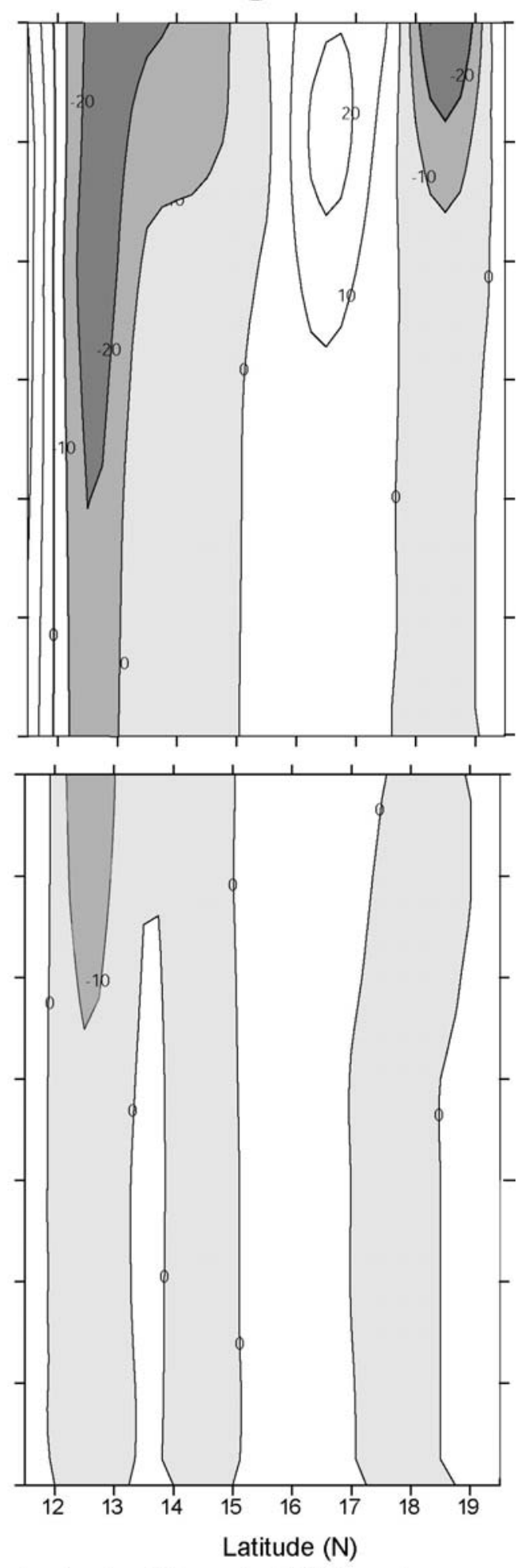

Fig.4 Vertical section of geostrophic velocity (cm/s) w.r.t. $1000 \mathrm{~m}$ along (a) central and (b) western boundary of the Bay of Bengal during fall intermonsoon 2002. Shading indicates westward flow while the flow in the rest of the region is eastward. 
(a)

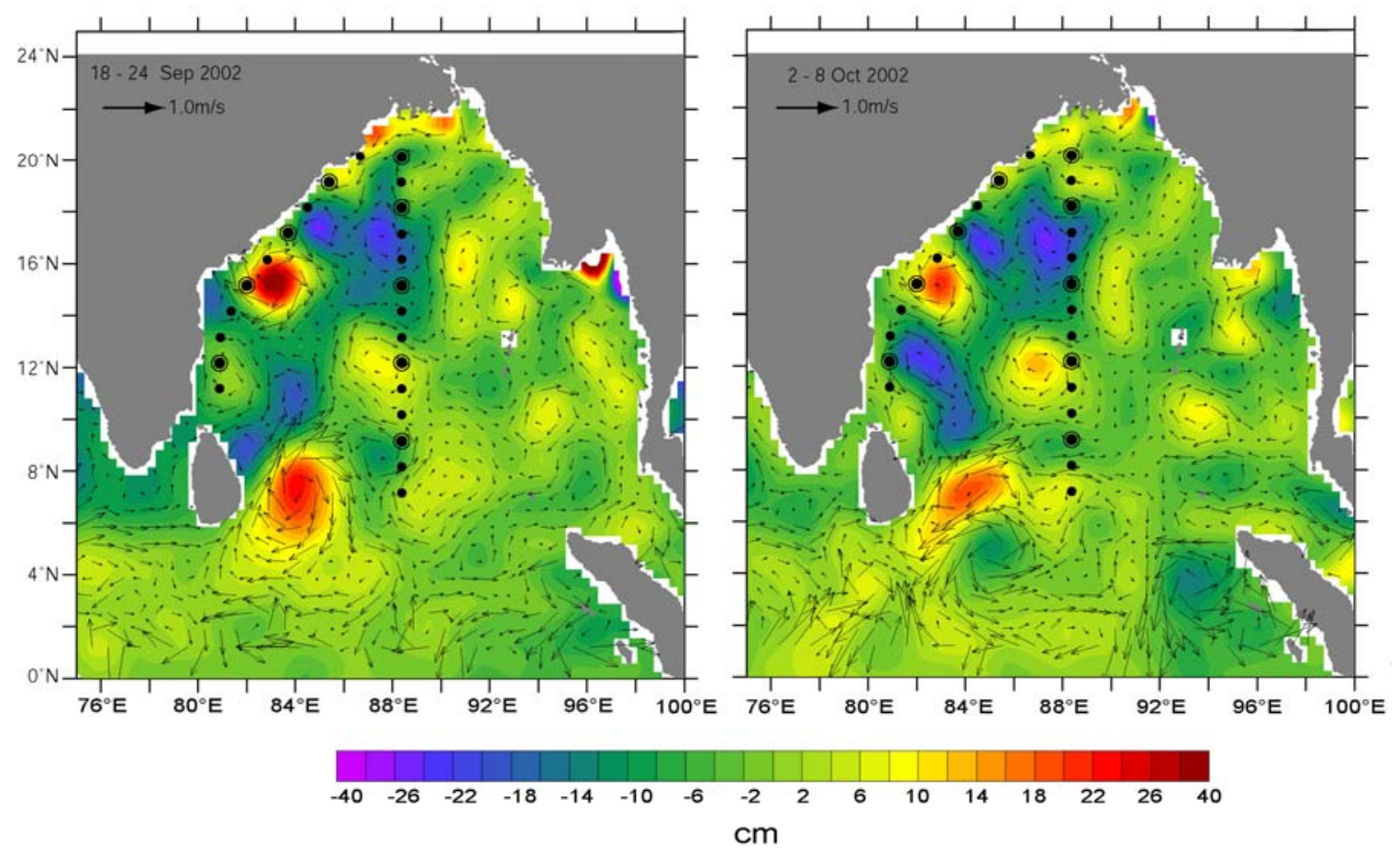

Fig.5 7-day snapshot of Topex/Poseidon ERS 1/2 merged sea-level anomalies overlaid with geostrophic velocities during (a) 18-24 September 2002 and (b) 2-8 October 2002 which is close to the period of CTD measurements along central (a) and western boundary (b) of the Bay of Bengal. Dark circles indicate CTD stations while open circles indicates the biological stations. 
(a)

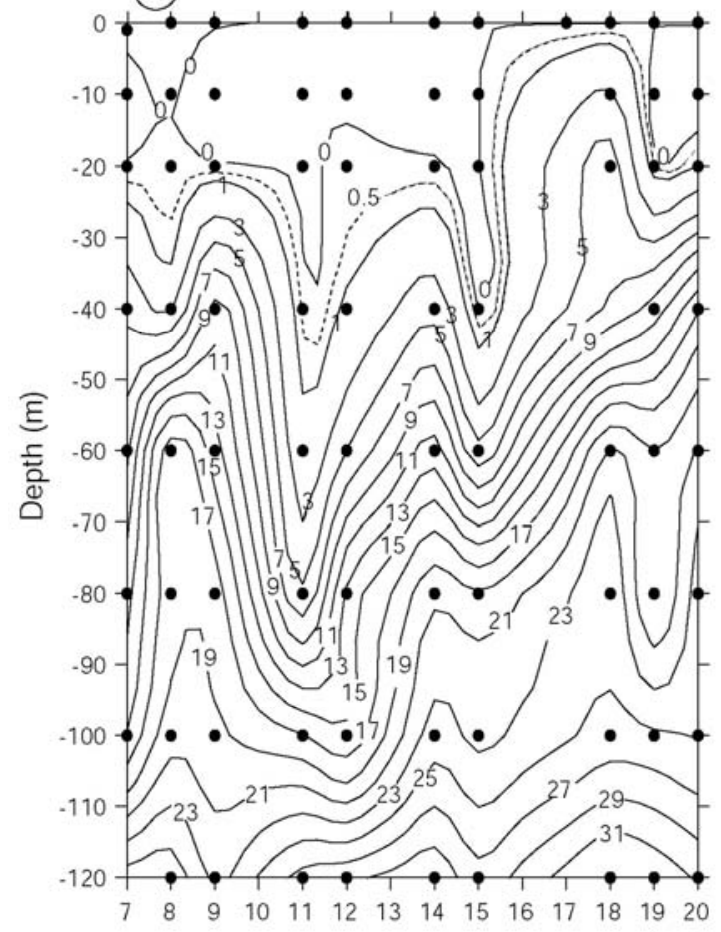

(b)

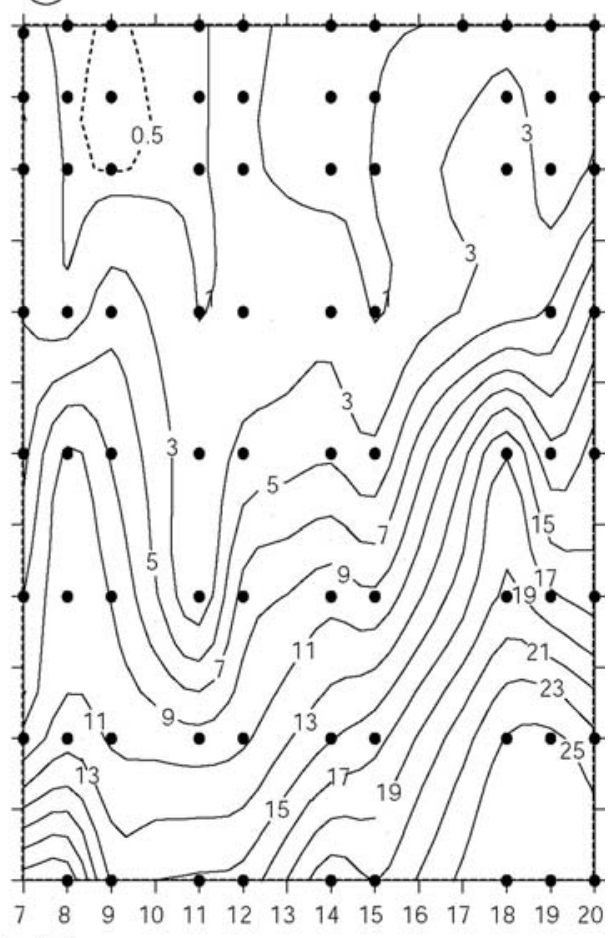

Latitude (N)

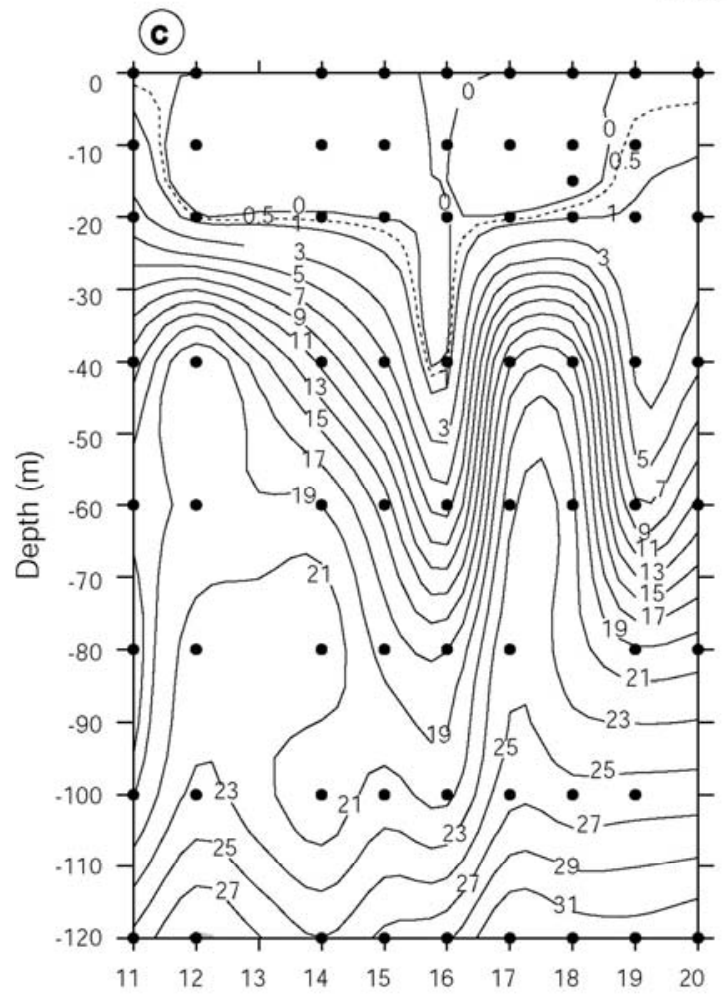

(d)

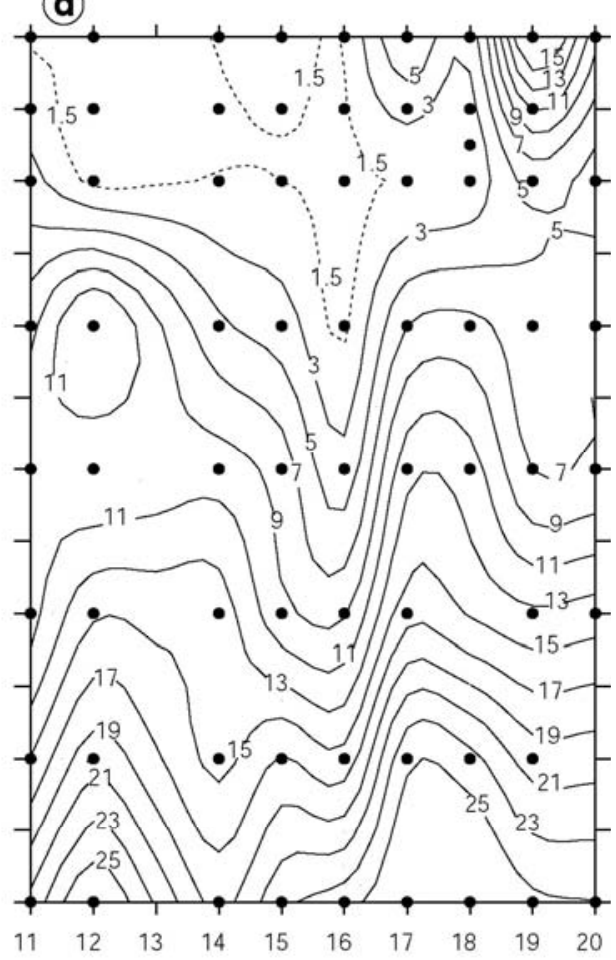

Latitude $(\mathrm{N})$

Fig.6 Vertical section of (left) nitrate $\left(\mu \mathrm{mol} \mathrm{L}^{-1}\right)(\mathrm{a}, \mathrm{c})$ and (right) silicate $\left(\mu \mathrm{mol} \mathrm{L} \mathrm{L}^{-1}\right)(\mathrm{b}, \mathrm{d})$ along (top) the central Bay of Bengal $\left(88^{\circ} E\right)(a, b)$ and (bottom) the western boundary $(c, d)$ during fall intermonsoon 2002. Zero (0) indicates concentrations below detection level. Note the change in contour interval of dashed line which is $0.5 \mu \mathrm{mol} \mathrm{L^{-1 }}$. Dark circles indicate sample locations. 

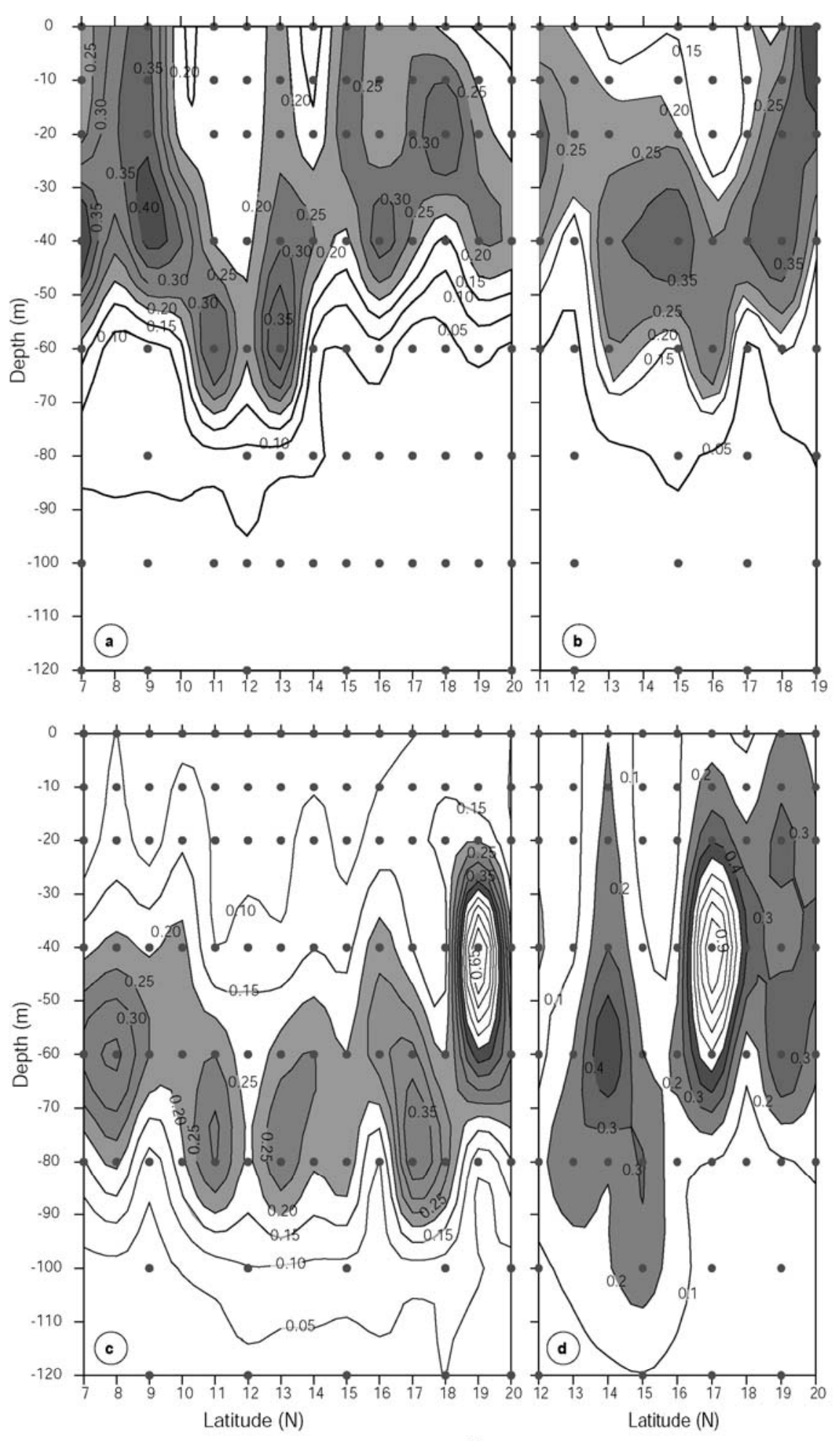

Fig. 7 Vertical distribution of chlorophyll $a\left(\mathrm{mg} / \mathrm{m}^{3}\right)$ along (left) the central Bay of Bengal $\left(88^{\circ} \mathrm{E}\right)(\mathrm{a}, \mathrm{c})$ and (right) the western boundary $(\mathrm{b}, \mathrm{d})$ during (top) fall intermonson $2002(\mathrm{a}, \mathrm{b})$ and (bottom) spring intermonson 2003 (c,d). Dark circles indicate sample locations. Note that shading is removed for chlorophyll a concentration $<0.2 \mathrm{mg} / \mathrm{m}^{3}$ in $(a, b)$ and for concentrations $>0.4 \mathrm{mg} / \mathrm{m}^{3}$ and $<0.2 \mathrm{mg} / \mathrm{m}^{3}$ in $(\mathrm{c}, \mathrm{d})$. 
(a)

(b)

(C)

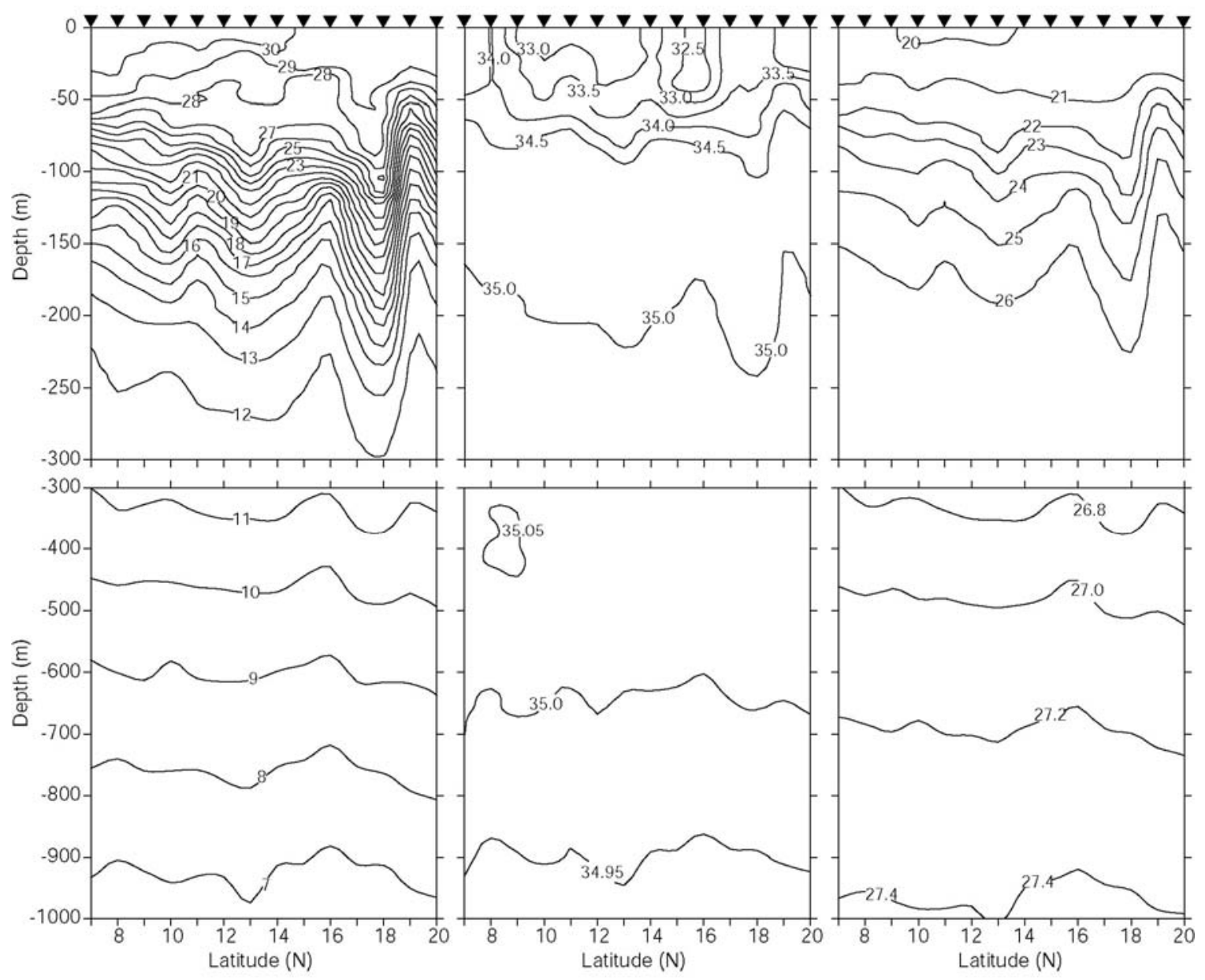

Fig. 8 Vertical section of (a) temperature $\left({ }^{\circ} \mathrm{C}\right)$, (b) salinity, and (c) sigma- $t\left(\mathrm{~kg} / \mathrm{m}^{3}\right)$ along the central Bay of Bengal ( $\left.88^{\circ} \mathrm{E}\right)$ during spring intermonsoon 2003 . Filled inverted triangles ( $\mathbf{v}$ ) on the top indicate the locations of CTD stations. 
(a)

(b)

(c)
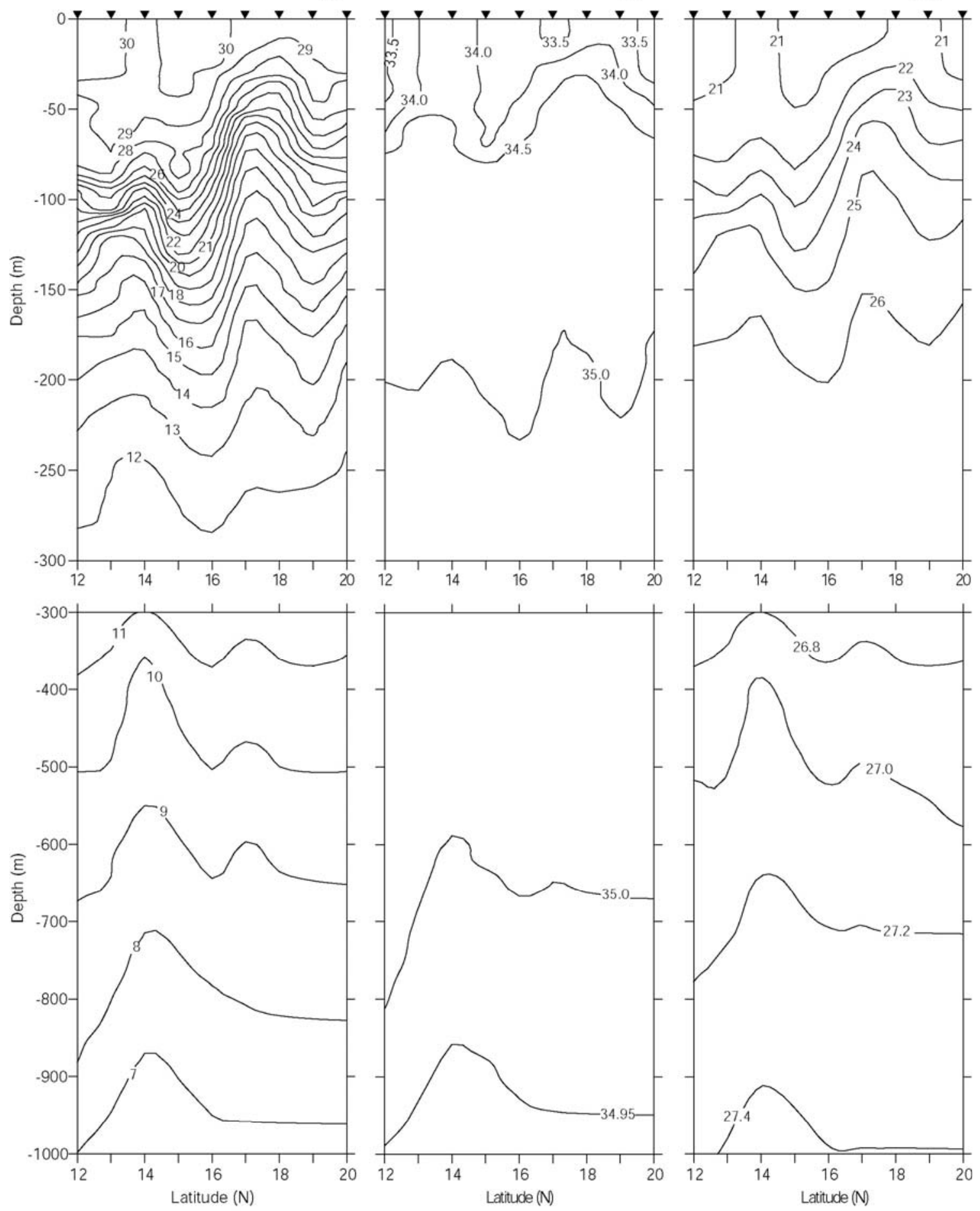

Fig.9 Vertical sectrion of (a) temperature ( $\left.{ }^{\circ} \mathrm{C}\right)$, (b) salinity, and (c) sigma- $t$ $\left(\mathrm{kg} / \mathrm{m}^{3}\right)$ along the western boundary of the Bay of Bengal during spring intermonsoon 2003. Filled inverted trianngles ( $\mathbf{v}$ ) on the top indicate the locations of CTD stations. 
(a)

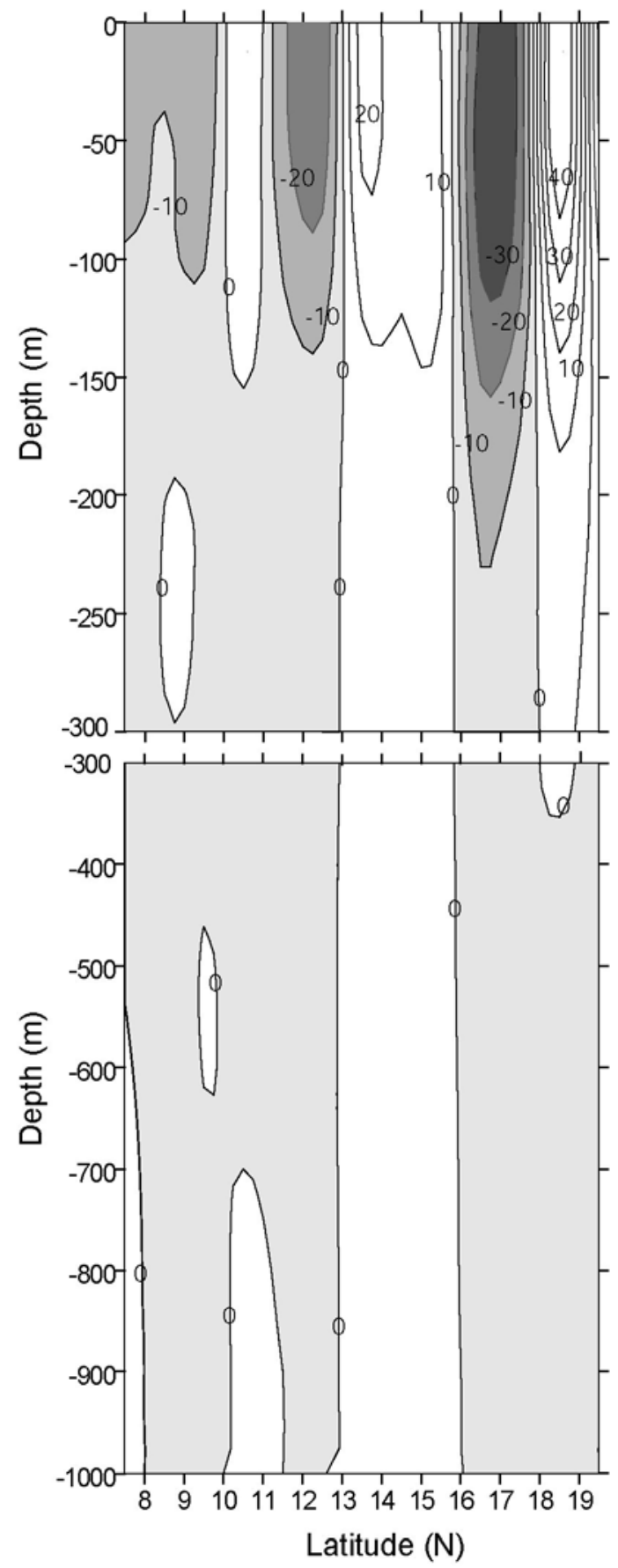

(b)
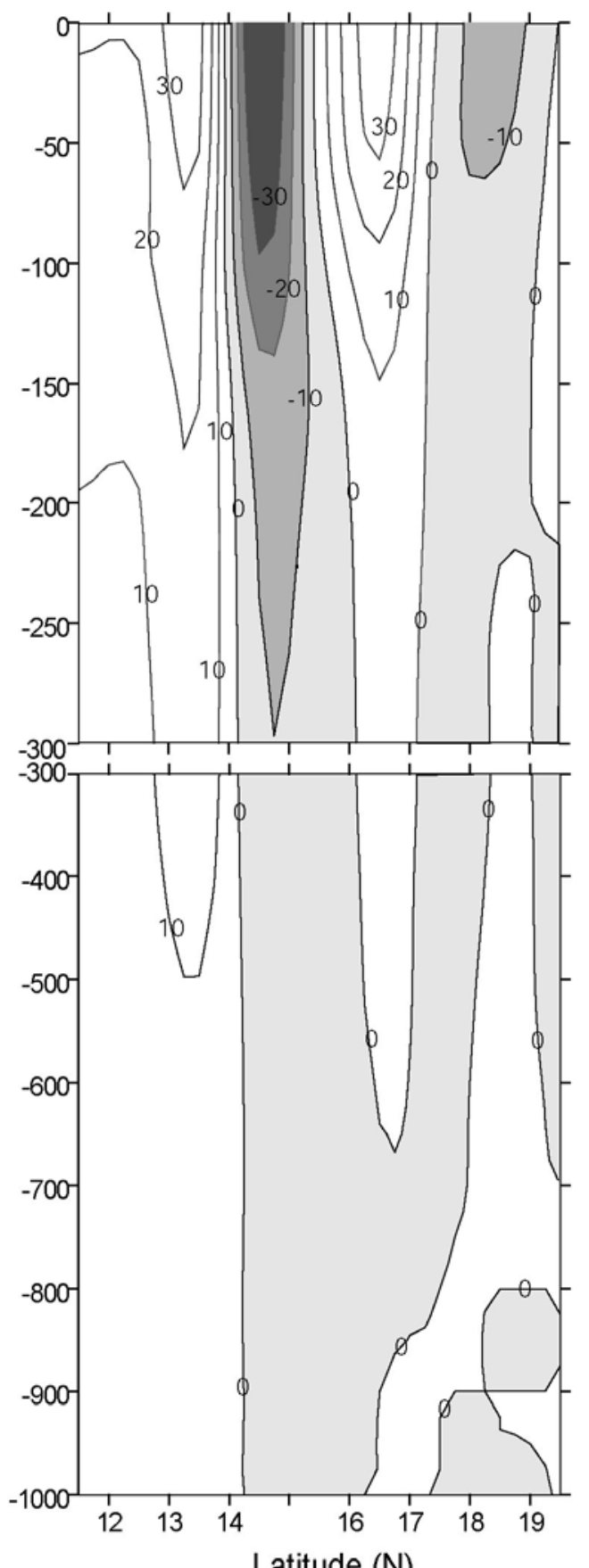

Fig.10 Vertical section of geostrophic velocity $(\mathrm{cm} / \mathrm{s})$ w.r.t. $1000 \mathrm{~m}$ along (a) central (b) western boundary of the Bay of Bengal during spring intermonsoon 2003. Shading indicates westward flow, while the flow in the rest of the region is eastward. 
(a)

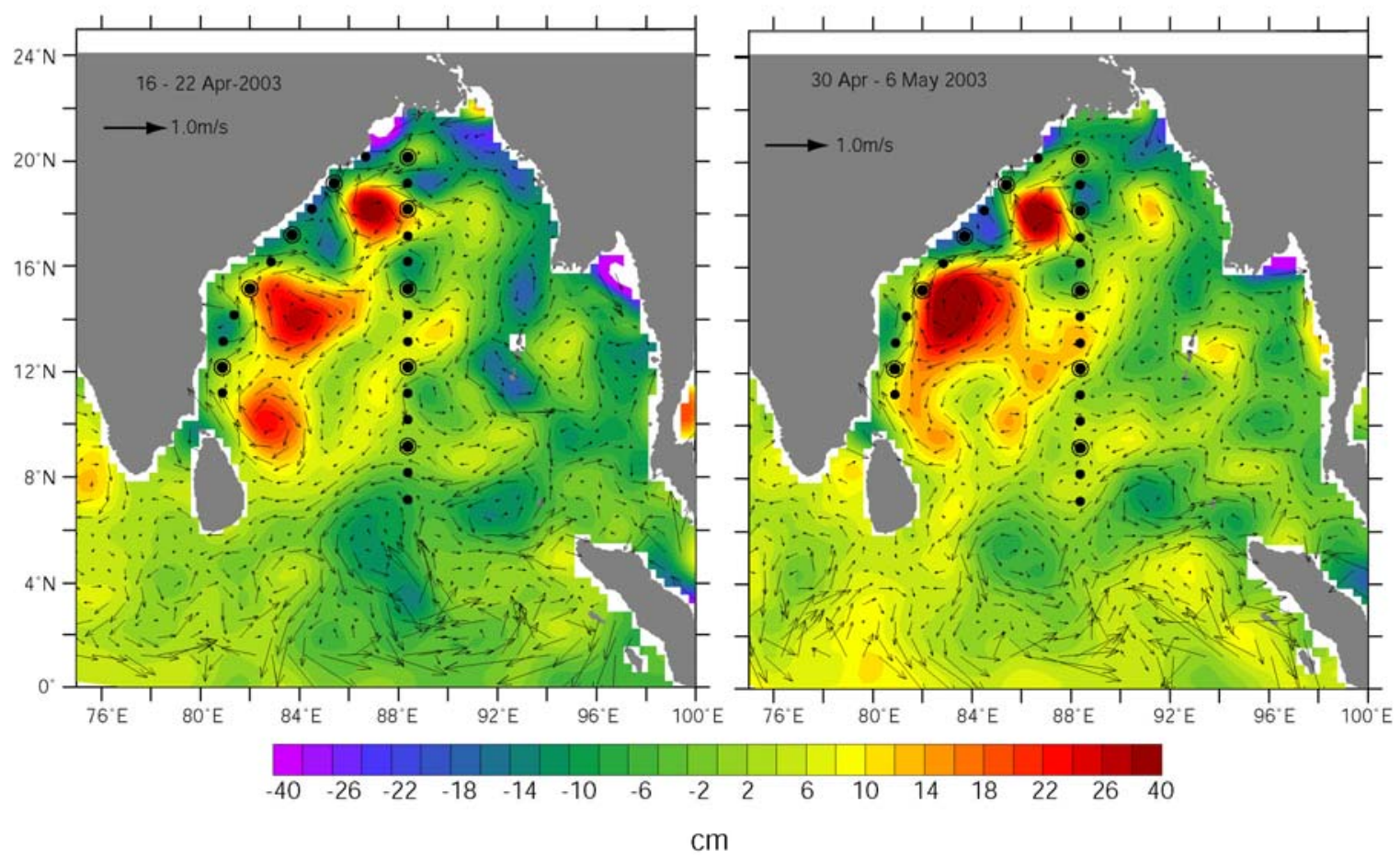

Fig.11 7-day snapshot of Topex/Poseidon ERS 1/2 merged sea-level anomalies overlaid with geostrophic velocities during (a) 16-22 April 2003 and (b) 30 April-6 May 2003 which is close to the period of CTD measurements along central (a) and western boundary (b) of the Bay of Bengal. Dark circles indicate CTD stations while open circles indicates the biological stations. 

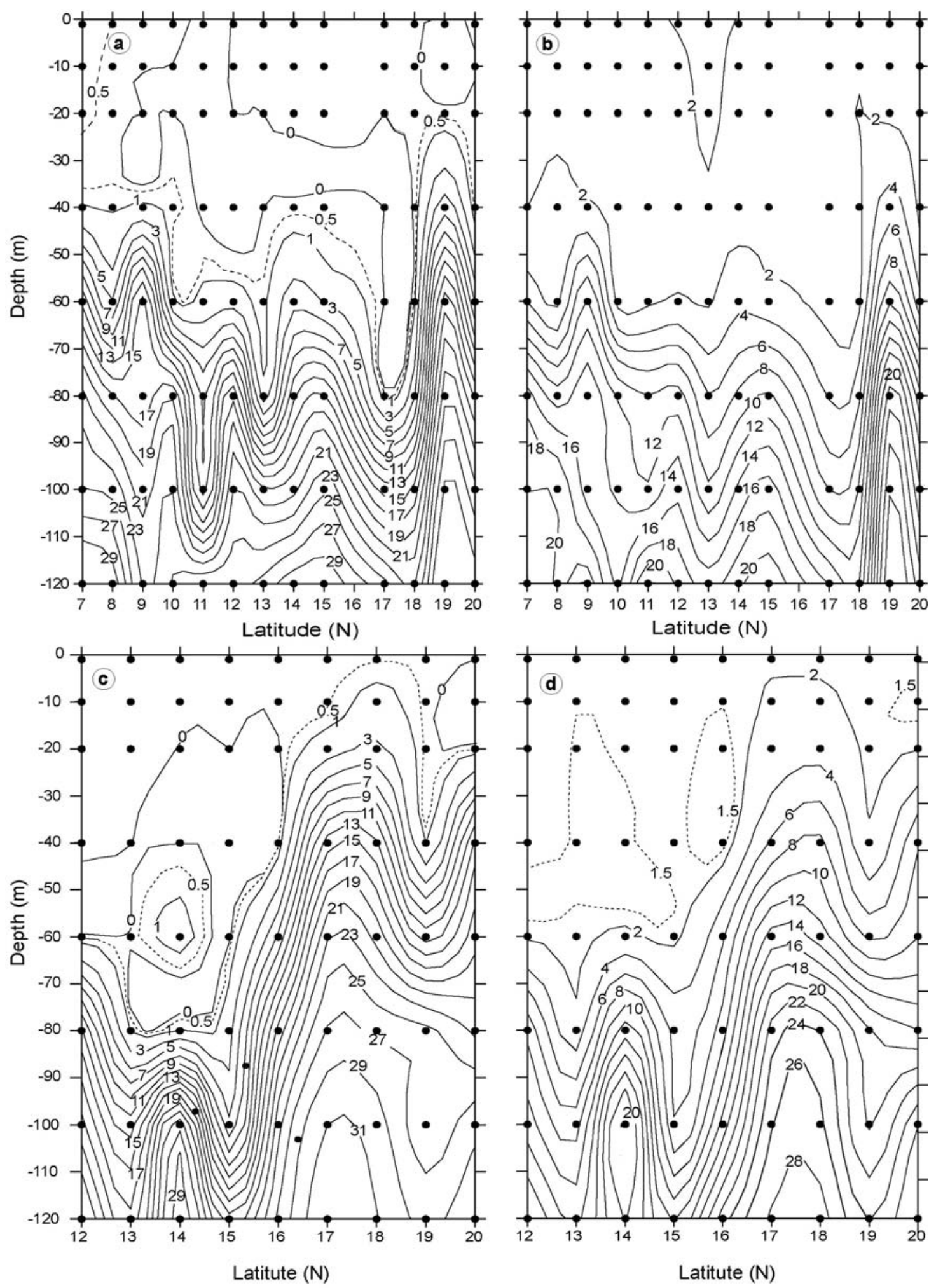

Fig.12 Vertical section of (left) nitrate $\left(\mu \mathrm{mol} \mathrm{L}^{-1}\right)(\mathrm{a}, \mathrm{c})$ and (right) silicate ( $\left.\mu \mathrm{mol} \mathrm{L-1}\right)$ $(b, d)$ along (top) the central Bay of Bengal $\left(88^{\circ} \mathrm{E}\right)(a, b)$ and (bottom) the western boundary (c,d) during spring Intermonsoon 2003. Zero (0) indicates concentration below detection level. Note the change in contour interval of dashed line, which is 0.5 $\mu \mathrm{mol} \mathrm{L}-1$. Dark circles indicate sample location. 

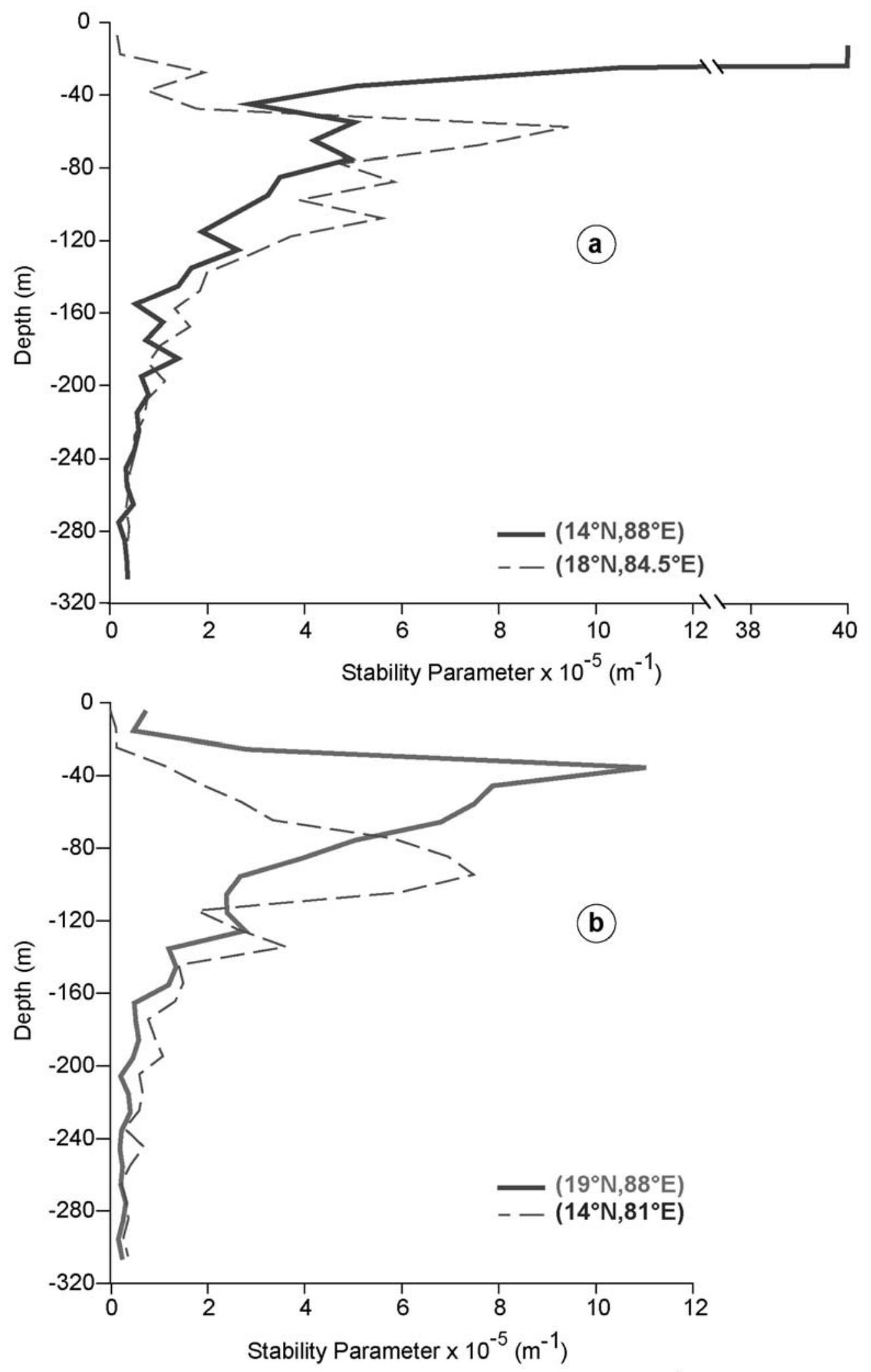

Fig. 13 Profiles of upper ocean static stability parameter $\left(E, \mathrm{~m}^{-1}\right)$ at (a) $18^{\circ} \mathrm{N}, 84.5^{\circ} \mathrm{E}$ and $14^{\circ} \mathrm{N}, 88^{\circ} \mathrm{E}$ during fall intermonsoon 2002 and (b) $19^{\circ} \mathrm{N}, 88^{\circ} \mathrm{E}$ and $14^{\circ} \mathrm{N}, 81^{\circ} \mathrm{E}$ during spring intermonsoon 2003. 

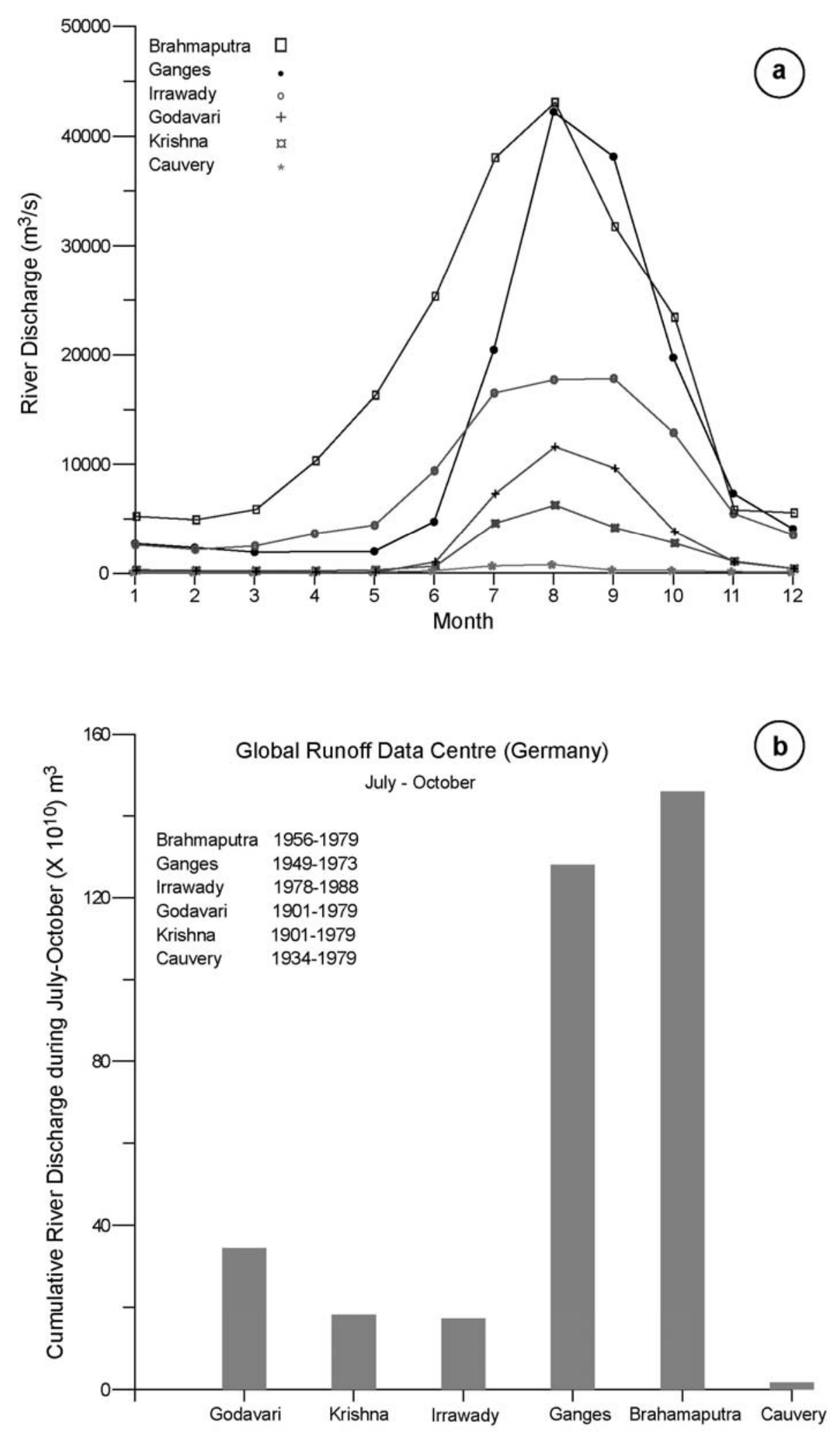

Fig. 14 Climatology of (a) monthly mean river discharge $\left(\mathrm{m}^{3} / \mathrm{s}\right)$ and $(b)$ cumulative dischage $\left(\mathrm{m}^{3}\right)$ during July to October of rivers Ganges, Brahmaputra, Irrawady, Godavari, Krishna and Cauvery. The river dischage data was obtained from Global Runoff Data Center, Germany (http://grdc.bafg.de/servlet/is/2781/). 